\title{
The influence of mesoscale eddies on a commercial fishery in the coastal waters of the Andaman and Nicobar Islands, India
}

\author{
Anand Arur $^{\mathrm{a} *}$, P. Krishnan ${ }^{\mathrm{b} \dagger}$, Grinson George ${ }^{\mathrm{b} *}$, M. P. Goutham Bharathi ${ }^{\mathrm{b}}$, \\ M. Kaliyamoorthy ${ }^{b}$, K. Hareef Baba Shaeb ${ }^{\mathrm{a}}$, A. S. Suryavanshi ${ }^{\mathrm{a}}$, T. Srinivasa Kumar ${ }^{\mathrm{c}}$, \\ and A. K. Joshi ${ }^{\mathrm{a}}$ \\ ${ }^{a}$ Regional Remote Sensing Centre, NRSC, ISRO-DoS, Nagpur 440033, India; ${ }^{b}$ Central Agricultural \\ Research Institute, ICAR, Port Blair 744 101, Andaman and Nicobar Islands, India; ${ }^{c}$ Advisory \\ Services and Satellite Oceanography Group, Indian National Centre for Ocean Information \\ Services (INCOIS), Hyderabad 500090, India
}

(Received 19 February 2014; accepted 30 May 2014)

\begin{abstract}
Mesoscale eddies enhance the productivity in a stratified coastal environment by upwelling. The seas around the Andaman and Nicobar Islands have been found to have frequent mesoscale eddy activity. Commercial fishing grounds coincide with upwelling areas associated with cyclonic and anticyclonic eddies and also with areas between two adjacent eddies. There are different eddy zones supporting different types of fishing gears and fish. The current study aims at identifying the different zones of mesoscale eddies in the Andaman Sea and compares the productivity and fishing activity in each of them. Data collected from 454 commercial fishing trips in the Andaman Sea along with maps of sea level anomaly and Moderate Resolution Imaging Spectroradiometer (MODIS) global level 3 mapped thermal infrared (IR) daytime sea surface temperature (SST) from the Aqua and Terra satellites were used for the study. Known upwelling areas such as the periphery of anticyclonic and the core of cyclonic eddies showed higher catches in longlines, ring seines among the fishing gears, and among all the fish species groups. Downwelling areas such as the periphery of cyclonic and the core of anticyclonic eddies showed lower catches with ring seines and the fish species groups. Areas in between adjacent eddies were explored in this study and the fish captures in such areas were found to be different with types of fishing and the target fish group. The study shows results that link eddy activity with the performance of a fishery.
\end{abstract}

\section{Introduction}

Mesoscale eddies increase biological productivity by vertical and horizontal mixing of the water column in the pelagic zone (Yoder et al. 1981). The eddies reduce thermocline depth and bring nutrients to the photic zone, improving the productivity in stratified tropical and subtropical regions of the oceans (McGillicuddy et al. 1998). Eddies increase the local productivity in the oligotrophic regions of tropical oceans (Hyrenbach et al. 2006). Mesoscale eddies influence productivity at every trophic level, such as the primary production (Seki et al. 2001; Mizobata et al. 2002; Bakun 2006) and concentration of

\footnotetext{
*Corresponding author. Email: anand isro@rediffmail.com

${ }^{\dagger}$ Present address: National Centre for Sustainable Coastal Management, Ministry of Environment and Forests (MoEF), Koodal Building, Anna University Campus, Chennai 600025, India.

"Present address: Central Marine Fisheries Research Institute, P B. No. 1603, Ernakulam North P.O., Kochi 682 018, India.
} 
zooplankton, micro-nekton (Sabarros et al. 2009), and plankton feeders (Olson and Backus 1985), which in turn form a forage base and attract tertiary-level producers (tunas, marlin, turtles, sea birds, and cetaceans).

Local oceanographic conditions such as fronts and eddies enhance primary productivity and thus attract pelagic planktivorous fishes, which in turn attract foraging predators to those areas (Laurs, Fiedler, and Montgomery 1984; Fiedler and Bernard 1987; Seki et al. 2001). Commercial fishing vessels scout and exploit the ideal conditions of mesoscale eddies, leading to an increase in catch per effort for pelagic species (Zainuddin et al. 2006; Seki et al. 2001). Satellite-based remote sensing of bio-optical parameters such as chlorophyll and thermal parameters such as sea surface temperature (SST) have contributed significantly to the understanding of ocean processes. Satellite altimetry has contributed significantly to physical oceanography. It provides accurate global sea surface height (SSH) measurements and anomalies and is useful for identifying and mapping mesoscale eddies and regional circulation such as frontal zones, internal waves, meanders, and upwelling. Merged altimeter products generated from multiple altimetry missions are used in tracking mesoscale processes (Ducet and Le Traon 1999). The synergy between altimeter-based SSH, ocean colour-based chlorophyll, and thermal/microwave-based SST in understanding mesoscale features has been demonstrated (Stapleton et al. 2002; Crawford, Brickley, and Thomas 2007; Chaigneau et al. 2013; Kurczyn et al. 2013; José et al. 2014). An altimeter can see through clouds and mild rain and forms a good substitute for ocean colour and thermal data in tracking mesoscale eddies under cloud cover.

Mesoscale eddies are observed in the coastal waters of the Andaman and Nicobar Islands (ANI) (Chen et al. 2013; Prasanna-Kumar, Nuncio, and Narvekar 2004; Hacker et al. 1998). Altimetry data gave us the first opportunity to examine the effects of eddies on the local fishery of the ANI. The Indian National Centre for Ocean Information Services (INCOIS) provides remote-sensing-based potential fishing zone (PFZ) forecasts to fishermen in the islands (Grinson et al. 2011, 2013). The forecasts are based on chlorophyll and SST maps retrieved from ocean colour and thermal imagery, respectively (Solanki et al. 2005). The islands are under cloud cover for about eight months of the year, which obscures optical and thermal imagery and hinders the generation of PFZ advisories (Grinson et al. 2014). The all-weather capability of altimeter data, and their ability to identify mesoscale eddies and established relationships between eddies and fisheries in other parts of the world, prompted this study. The objective of the study is to examine the effect of eddies on the catches from the ANI fishery, with the future goal of using altimeter data in operational fishery advisories.

\section{Study area}

The ANI are located between $60^{\circ} 45^{\prime} \mathrm{N}$ and $130^{\circ} 41^{\prime} \mathrm{N}$ and $92^{\circ} 12^{\prime} \mathrm{E}$ and $93^{\circ} 57^{\prime} \mathrm{E}$ in the Eastern Indian Ocean, separating the Bay of Bengal (BoB) from the Andaman Sea (Figure 1). The oceanic islands form the largest archipelago in the $\mathrm{BoB}$, comprising 572 islands, islets, and rocky outcrops (ANDFISH 2005). The marine fish production in the ANI is about 30,000 tons, constituting $19 \%$ of the estimated potential of exploitable pelagic and demersal fish stock (Roy and George 2010). Pelagic fish such as mackerel, sardines, clupeids, tuna, and scombrids formed $85 \%$ of the total potential fishery resource available in the ANI (ANDFISH 2005). The marine fishery in the ANI is dominated by pelagic catches, which comprise about $60 \%$ of the total catch. Gillnet (27\%), handline (54\%), longline (5\%), and ring net/seine (1\%) are the major types of fishing gears used in the Andaman fishery (FSI 2007). 


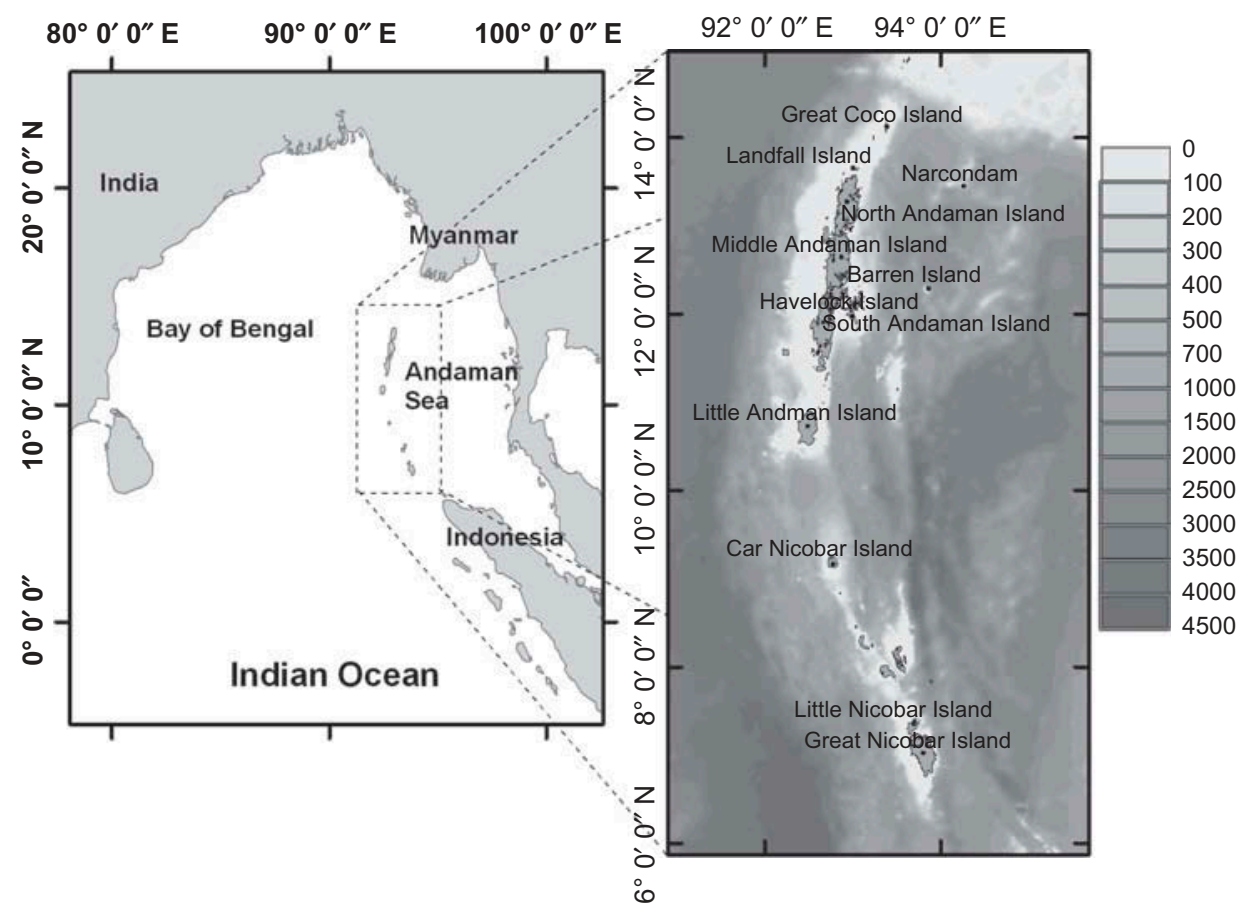

Figure 1. Map of the study area.

\section{Materials and methods}

\subsection{Collection of fish catch data}

Fish catch data were collected from 454 commercial fishing trips deploying ring seine $(n=143)$, longline $(n=178)$, gillnet $(n=68)$, handline $(n=37)$, and trawl $(n=28)$ during August 2010 to February 2012 (Table 1).

The catch data log used for data collection of fishing variables included general information such as date, haul locations recorded by GPS (deployment and hauling), crew number, vessel length, vessel registration number, fishing gear type and specification, qualitative oceanographic observations (depth of operation, colour of sea, and nature of sea and seabed), fish haul details (duration of haul, quantity, species, and composition), and economic variables (quantity of ration, fuel, ice, and bait). Records were maintained for each haul and consolidated for a fishing day. The fishing vessels were equipped with GPS and operated from Diglipur, Dignabad, Guptapara, Junglighat, Panighat, Rangat, and Wandoor fishing harbours in the ANI.

\subsection{Satellite data and sea level anomaly maps}

Near real time and delayed time maps of mean sea level anomaly (NRT and DT-MSLA) from Archiving, Validation and Interpretation of Satellite Oceanographic data (AVISO) (http://www.aviso.oceanobs.com/) were used for the study. The merged SLA data from multiple satellite products are produced by Ssalto/Duacs and distributed by AVISO. SLA data are provided with a spatial resolution of $1 / 3^{\circ}$ latitude/longitude. The update series was used for the study as it adds measurements from up to four different satellites 


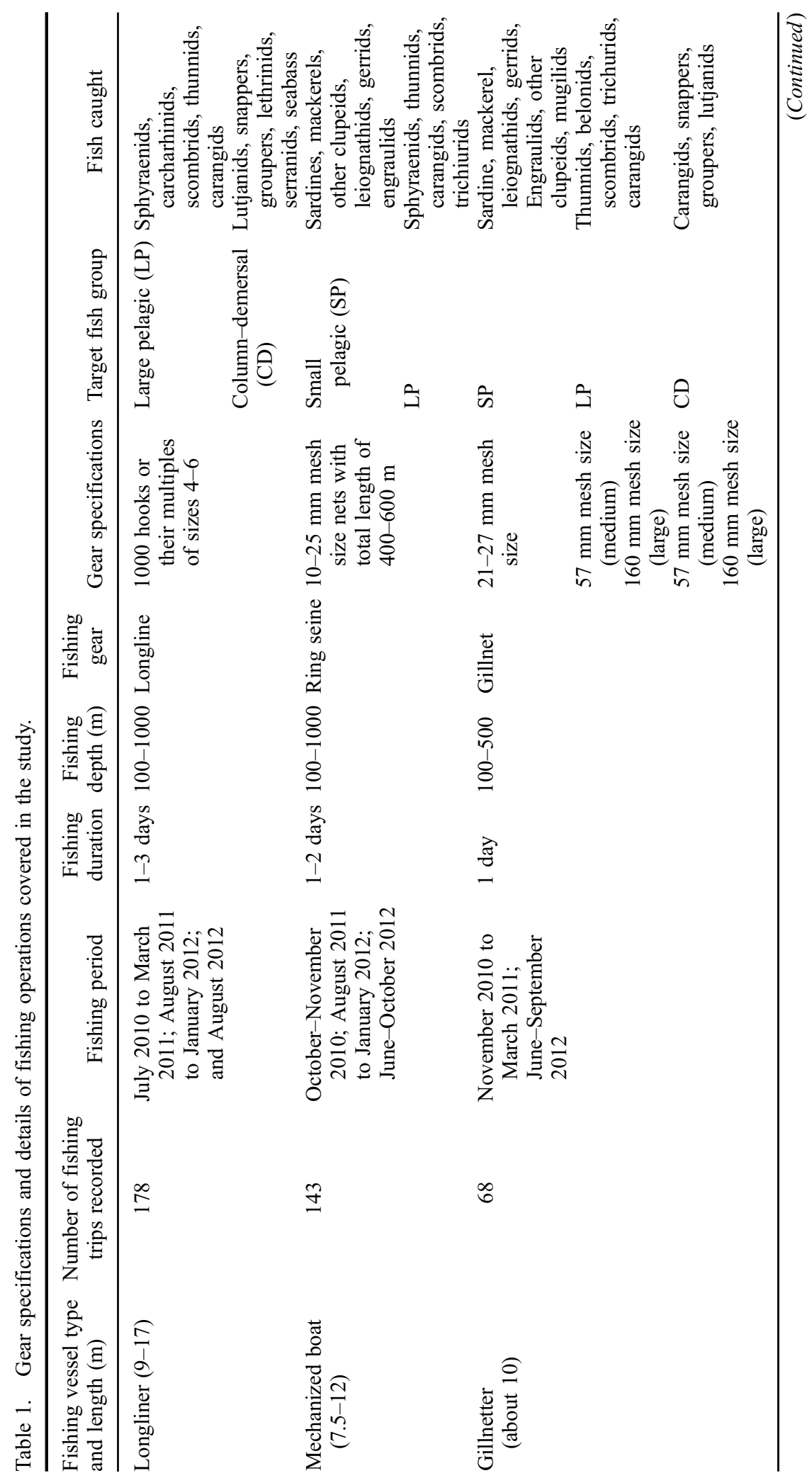




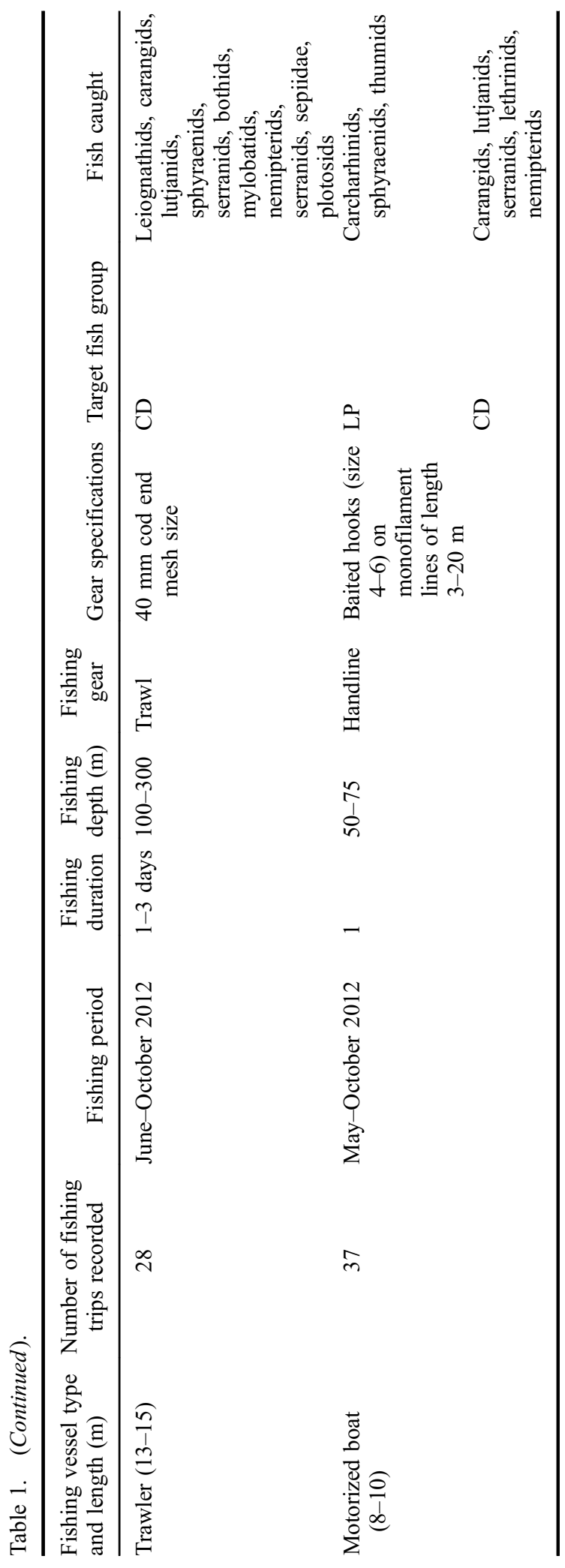


whenever a new satellite becomes available. The MSLA maps in NetCDF format from AVISO were processed using ArcGIS and converted into raster images by the spline interpolation technique. The interpolated MSLA map was used to generate contours of $1 \mathrm{~cm}$ interval. About 150 sets of SLA maps contemporary to the individual fishing trip data were used for overlay and analysis. Maps of absolute dynamic topography (MADT) with sea surface geostrophic zonal and meridional components $(u$ and $v)$ from AVISO were used for computing the geostrophic current.

For the satellite-derived SST, Moderate Resolution Imaging Spectroradiometer (MODIS) global level 3 mapped thermal infrared (IR) daytime SST from Aqua and Terra sensors, available at the Physical Oceanography Distributed Active Archive Center (PO.DAAC) site of NASA (http://podaac.jpl.nasa.gov), were used. For chlorophyll, MODIS global level 3 standard mapped image (SMI) eight-day composite maps from the OceanColor Web of GSFC-NASA (http://oceancolor.gsfc.nasa.gov/) were used. Both maps have $4 \mathrm{~km}$ spatial resolution, sufficient enough to recognize changes in the study domain. The above data were overlaid with SLA maps to examine the productivity linked to eddies in Andaman Sea.

\subsection{Delineation of eddy using SLA maps}

\subsubsection{Delineation of eddy}

An approach similar to the SSH-based eddy identification procedure of Chelton, Schlax, and Samelson (2011) was adopted. Eddies, the largest regions that satisfy the specific eddy definition criteria of Chelton, Schlax, and Samelson (2011), were identified by a manual approach. SLA contours generated at $1 \mathrm{~cm}$ interval from the maps were used. The outermost closed contour with a compact structure resembling a vortex, with minimum $1 \mathrm{~cm}$ amplitude, was identified as an eddy. Eddies were identified as either cyclonic or anticyclonic by the type of anomaly within the bounding contour. Cyclonic eddies that rotate in an anticlockwise direction have a negative SLA anomaly with a depressed core and anticyclonic eddies that rotate in a clockwise direction have a positive SLA anomaly with an elevated core, within the bounding contour.

\subsubsection{Identification of eddy zones}

While techniques of eddy delineation from satellite altimetry fields are fairly well established, further division of eddies into regions has been attempted by very few. LindoAtichati et al. (2012) classified altimeter SSH fields and derived cyclonic and anticyclonic eddies into core and boundary regions, using the standard deviation of SSH and the standard deviation of the absolute value of the gradient of SSH in the Gulf of Mexico. This method was used again by Lindo-Atichati, Bringas, and Goni (2013) for studying the loop current in the Gulf of Mexico. A simplified version of the zoning approach of Lindo-Atichati et al. (2012) using the mean value of SLA within the eddy bounding contour, instead of standard deviation and gradient of SSH of entire region, was followed in this study to delineate eddy zones. Initially, eddy amplitude $\left(h_{\max }-h_{\min }\right)$ to eddy radius ratios were computed from randomly selected eddies, cyclonic $(n=30)$ and anticyclonic $(n=30)$, falling in the fishing areas. This ratio is considered a measure of eddy strength (Kobayashi et al. 2011) and had a range of $0.1-0.9$, with $90 \%$ of the selected eddies falling in the range $0.1-0.4$, which were considered as low-to-moderate eddy strength for the region. The difficulty in exactly delineating the region of interest around the ANI (the ANI is an archipelago situated 
between the vast seas of Andaman and $\mathrm{BoB}$ ) for the purpose of computation of SLA statistics of the region and the observation of low-to-moderate eddy strengths in the fishing regions prompted a simplified approach of partitioning the core and periphery of eddy using the mean SLA in the eddy. Even though the current method assumes the mean SLA in the eddy to be separating the core from periphery, the actual separation would be dependent on various characteristics of the eddy including the age. The eddy zone separation technique can be improved further by more detailed studies on characteristics of eddies occurring in the region and using SLA gradient within the eddy bounding contour. This simplistic method is evolved to address the major objective of identifying the link between eddies and commercial fishery of the region.

After identifying the eddy bounding contours (cyclonic and anticyclonic), they were partitioned into core and periphery by generating an intermediate contour at $\left(h_{\max }+h_{\min }\right) / 2$, where $h_{\max }$ is the maximum SLA height $(\mathrm{cm})$ within the innermost and outermost contours and $h_{\min }$ is the minimum SLA height $(\mathrm{cm})$ of the outermost and innermost contours of anticyclonic and cyclonic eddies, respectively. This was done by generating $0.5 \mathrm{~cm}$ interval contours within the eddy bounding contour and retaining the intermediate contour, which approximates to the mean SLA within the eddy. Identification of both eddy bounding contour and median contour were done manually due to difficulties in automation of the procedure. Delineation of eddy zones is illustrated in Figure 2. Anticyclonic eddies were

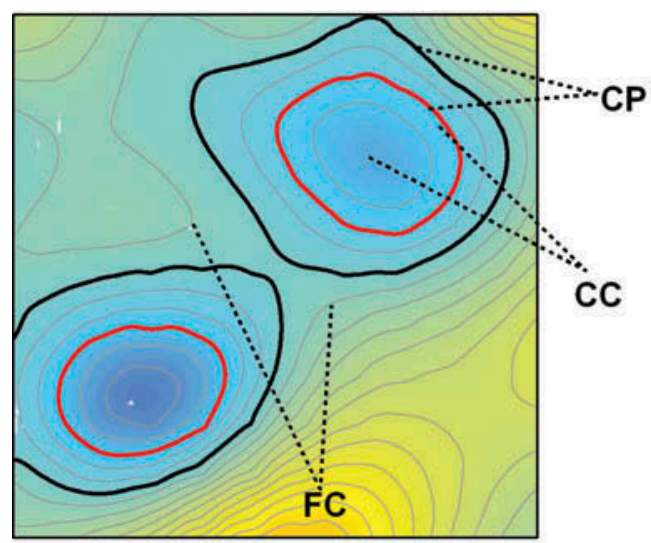

(a)

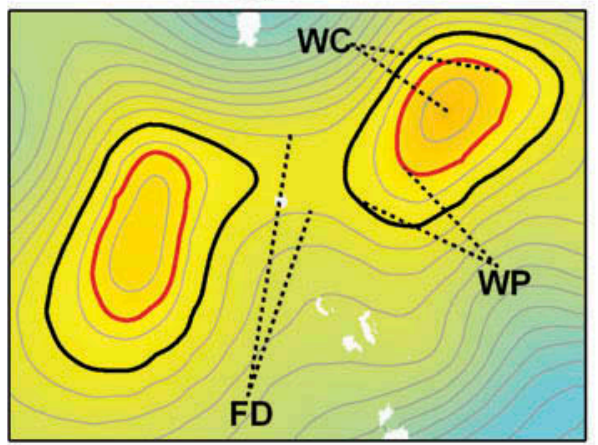

(c)

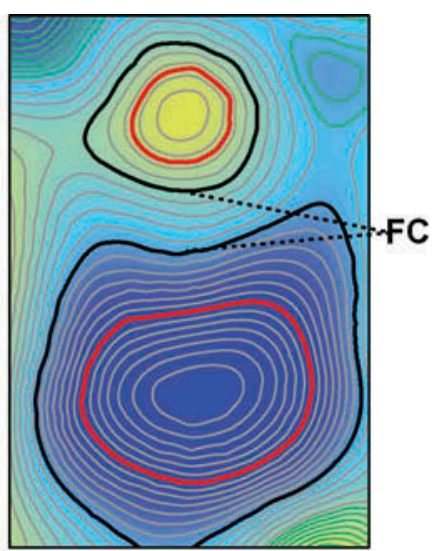

(b)

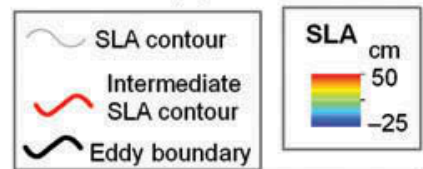

Eddy Zones

CC - Cyclonic (cold core) eddy central zone

CP - Cyclonic (cold core) eddy peripheral zone

WC - Anticyclonic (warm core) eddy central zone

WP - Anticyclonic (warm core) eddy peripheral zone

FC - Flows convergent

FD - Flows divergent

Figure 2. Delineation of eddy zones and interaction. (a) Cyclonic eddy pair, (b) cyclonic-anticyclonic eddy pair, and $(c)$ anticyclonic eddy pair. 
Table 2. Characteristics of different eddy zones.

\begin{tabular}{|c|c|c|c|}
\hline Eddy type & Eddy zone & Identification & Zone properties \\
\hline \multirow[t]{2}{*}{$\begin{array}{l}\text { Anticyclonic } \\
\text { (warm core) }\end{array}$} & Core (WC) & $\begin{array}{l}h_{\max } \text { and } \\
\quad\left(h_{\max }+h_{\min }\right) / 2\end{array}$ & $\begin{array}{l}\text { Elevated sea surface, area of convergence/ } \\
\text { downwelling, and not considered productive }\end{array}$ \\
\hline & $\begin{array}{l}\text { Periphery } \\
\text { (WP) }\end{array}$ & $\begin{array}{l}h_{\min } \text { and } \\
\quad\left(h_{\max }+h_{\min }\right) / 2\end{array}$ & $\begin{array}{l}\text { Depressed sea surface, divergence/upwelling } \\
\text { occurs, and is considered productive }\end{array}$ \\
\hline \multirow[t]{2}{*}{$\begin{array}{l}\text { Cyclonic } \\
\quad \text { (cold core) }\end{array}$} & Core $(\mathrm{CC})$ & $\begin{array}{l}h_{\max } \text { and } \\
\quad\left(h_{\max }+h_{\min }\right) / 2\end{array}$ & $\begin{array}{l}\text { Depressed sea surface, divergence/upwelling, } \\
\text { and considered productive }\end{array}$ \\
\hline & $\begin{array}{l}\text { Periphery } \\
\text { (CP) }\end{array}$ & $\begin{array}{l}h_{\min } \text { and } \\
\quad\left(h_{\max }+h_{\min }\right) / 2\end{array}$ & $\begin{array}{l}\text { Elevated sea surface, convergence/downwelling, } \\
\text { and not considered productive }\end{array}$ \\
\hline \multirow[t]{2}{*}{$\begin{array}{l}\text { Interaction } \\
\text { (between } \\
\text { eddies) }\end{array}$} & $\begin{array}{l}\text { Converging } \\
\text { flows (FC) }\end{array}$ & $\begin{array}{l}2 \text { cm contour } \\
\text { surrounding } \\
\text { the eddy }\end{array}$ & $\begin{array}{l}\text { Between cyclonic and cyclonic eddy pairs or } \\
\text { high-gradient area between cyclonic and } \\
\text { anticyclonic eddy pairs }\end{array}$ \\
\hline & $\begin{array}{l}\text { Diverging } \\
\text { flows (FD) }\end{array}$ & $\begin{array}{l}2 \text { cm contour } \\
\text { surrounding } \\
\text { the eddy }\end{array}$ & Between two anticyclonic eddy pairs \\
\hline Non-eddy & $\mathrm{NE}$ & $\begin{array}{l}\text { Beyond } 2 \mathrm{~cm} \\
\text { contour }\end{array}$ & Sea levels influenced by non-eddy processes \\
\hline
\end{tabular}

partitioned into warm core eddy centre (WC) and warm core eddy periphery (WP) and similarly cyclonic eddies into cold core eddy centre (CC) and cold core eddy periphery (CP). The regions within a $2 \mathrm{~cm}$ contour surrounding the compact eddy features were considered as frontal regions (Davis et al. 2002; Seki, Lumpkin, and Flament 2002; Chelton, Schlax, and Samelson 2011; Lindo-Atichati et al. 2012), where the eddies interact with nearby eddies and such areas include meanders and streamers. Interactions between eddies lead to converging flows (FC) and diverging flows (FD). Surface geostrophic currents derived from contemporary absolute geostrophic velocity maps from AVISO were used to ascertain the direction and speed of the current. The properties of different eddy zones delineated in the study are summarized in Table 2.

\subsection{GIS layer of fish catch and attributes}

The commercial fishery of the ANI is predominantly pelagic with a small share of demersal- and column-dwelling fish. In this study, groups of major species (irrespective of the fishing gear used) were examined for their relationships with eddy zones at catch locations. The catches from all fishing gears were segregated based on the major species in the haul into three major groups, i.e. small pelagics, large pelagics, and column/ demersal fishes (Table 1). A particular haul was classified into a group only if the representative group of fishes constituted more than $50 \%$ of the haul or day's catch as recorded in the data log. In order to identify the eddy zone at catch locations, geographical information system (GIS) layers containing catch locations along with attribute data were overlaid on contemporary MSLA raster images with contours. The fish catch locations were plotted on a GIS using ArcGIS. All the available catch positions for the two fishing years were plotted. The fishing trip details were then added as attributes to the catch locations linking with the catch ID and corresponding fishing data. Each fishing record finally consisted of three attributes, i.e. fishing gear, fish group, and eddy zone. 


\subsection{Statistical analysis of CPUE}

The fishing effort quantified as catch per unit effort (CPUE) was used to analyse the efficiency of the fishing gear and relationships between eddy zones and gear and fish groups. As the study involved five different types of fishing gears targeting different species, CPUE was calculated in kilogrammes of catch per fishing day. A minimum fishing operation for 12 hours qualified a fishing day. Multiple hauls in a day were consolidated into total catch per day. The CPUE from the catches were transformed to $\log _{10}$ CPUE to satisfy the assumption of normality for ANOVA. Welch ANOVA (Welch 1951) was carried out with the Games-Howell pairwise test for post hoc analysis.

Initially, 454 catch data sorted on the basis of fishing gear and $\log _{10}$ CPUE were subjected to Welch ANOVA to test significance of means. Subsequently, data were sorted based on different eddy zones and finally the three fish groups and tested for Welch ANOVA.

At the second level, the data were sorted for popular fishing gear, viz. longline, ring seine, and gillnet. The significance of means of $\log _{10}$ CPUE at different eddy zones for each piece of fishing gear was tested by Welch ANOVA and Games-Howell pairwise tests. Similar steps were done for fish groups and different eddy zones for each fish group.

\section{Results}

\subsection{Fishing data}

The commercial fishery of the ANI has two major seasons, from August to November and January to April, which are the inter-monsoon periods between the southwest monsoon (May-August) and northeast monsoon (November-January). The peak fishing seasons occur between September-November and January-March. The fishery of the ANI is a tropical multi-species fishery with a higher proportion of pelagic species. Plots of catches (Figure 3) from the three major types of fishing gears show the temporal variations in CPUE during the study period. CPUEs are observed to be higher for longlines and ring seine during 2010 as compared to the subsequent period. A general decrease in CPUE from 2010 to 2011 followed by recovery in 2012 is seen in the longline and ring seine catches. The reason behind the drop in CPUEs in 2011 needs further investigation. The eddy zone at the place of capture is depicted by different symbols in the figure. As the study focused on identifying the eddy type and zone at the place of capture, the seasonality and frequency of eddies in the region were not to be studied in detail. The fishing craft and gear used and the types of fishes caught during the study period are summarized in Table 1. Catch locations overlaid on eddy maps showed that $44 \%$ of the catches were taken at non-eddy (NE) areas, 30\% at eddy peripheries (anticyclonic and cyclonic), $15 \%$ at areas of eddy interaction (FD and $\mathrm{FC}$ ), and $10 \%$ at eddy core areas (CC and WC).

\subsection{Ocean colour and SST data}

Chlorophyll and SST maps corresponding to the MSLA data showed gaps due to persistent cloud cover around the islands during May to September. The period of October to April was relatively cloud free. SLA contours and geostrophic current overlaid on the chlorophyll maps showed increase in chlorophyll at eddy zones CC, WP, FD, and FC (Figures 4 and 5). However, the increase in chlorophyll at these zones was not accompanied by changes in SST. 

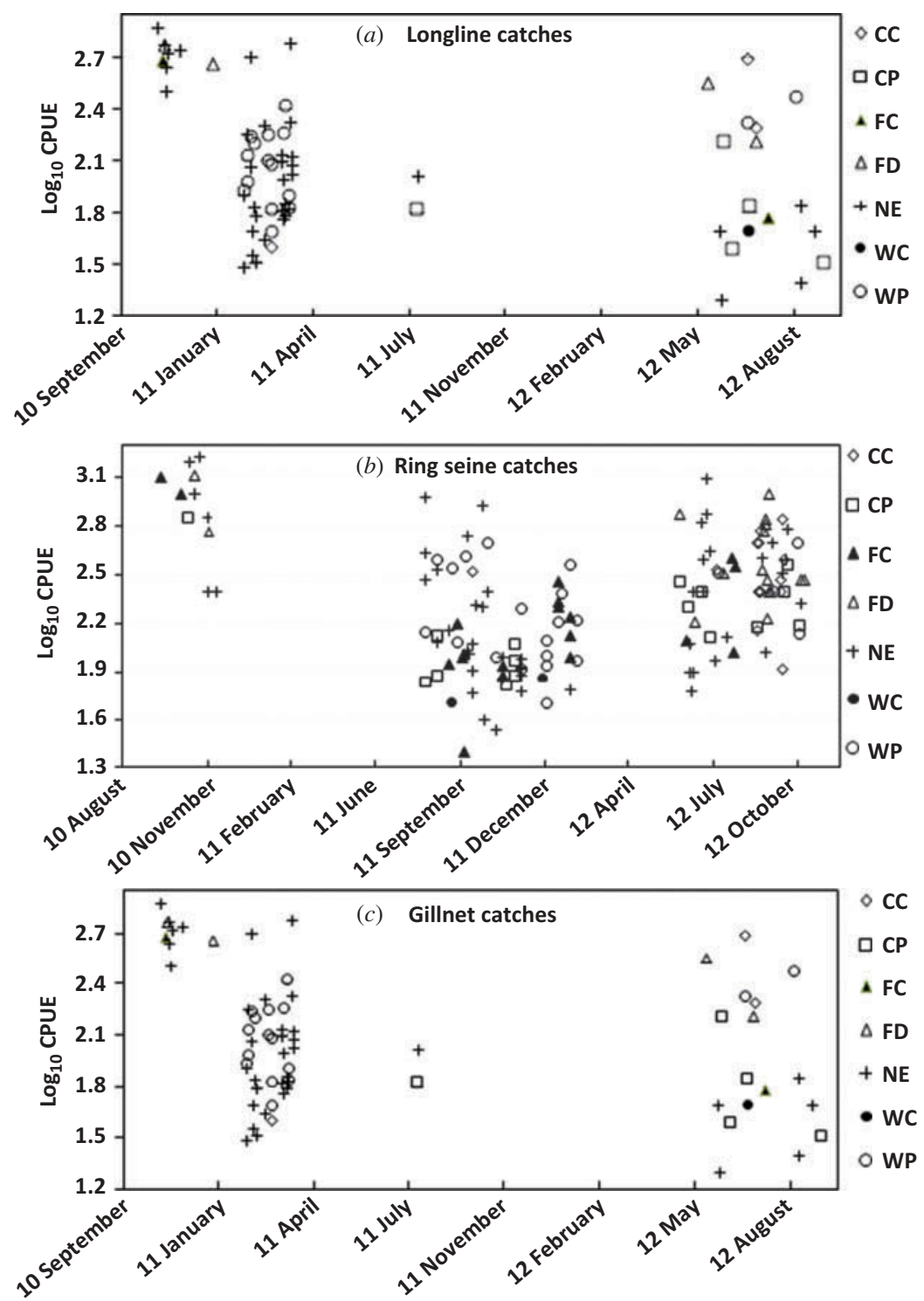

\begin{tabular}{|c|c|}
\hline CC-Cyclonic eddy core & WC-Anticyclonic eddy core \\
\hline CP-Cyclonic eddy periphery & WP-Anticyclonic eddy periphery \\
\hline FC-Flows convergent & NE-Non-eddy region \\
\hline
\end{tabular}

Figure 3. Plots of CPUE of (a) longline, $(b)$ ring seine, and $(c)$ gillnet catches taken in the study. Eddy zone at the location of capture is represented by different symbols.

\subsection{Analysis of variance in CPUE}

The study showed that the mean CPUE varied significantly $(p<0.001)$ among the fishing gears used (Table 3). Ring seine had the highest mean CPUE followed by trawl, gillnet, hook and line, and handline, while the variation in CPUE between gillnet and longline was not significant $(p>0.01)$ (Table 4$)$. 


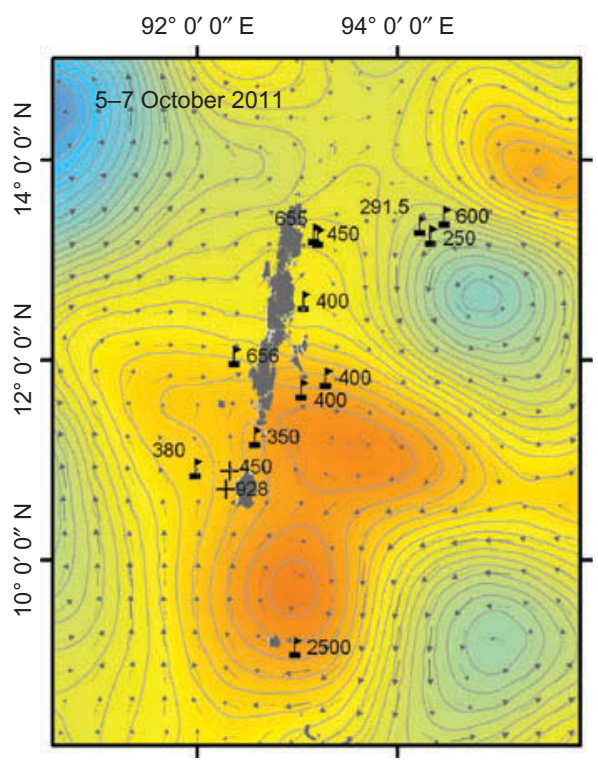

(a)

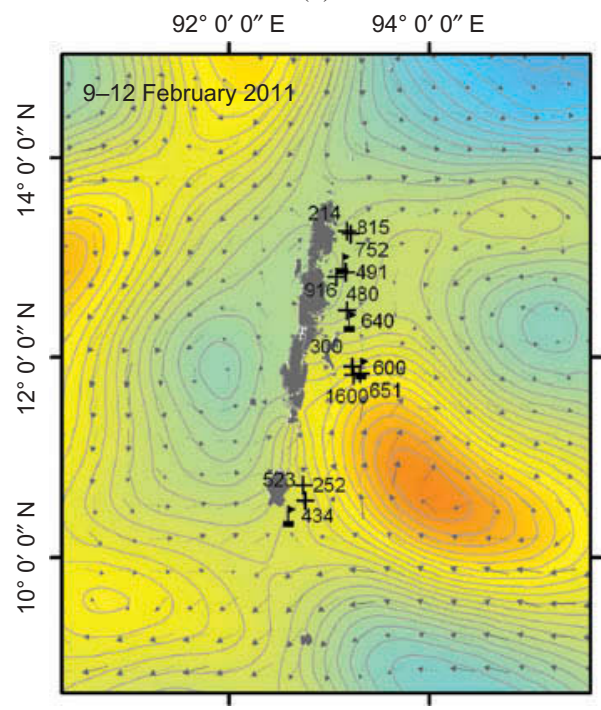

$(c)$

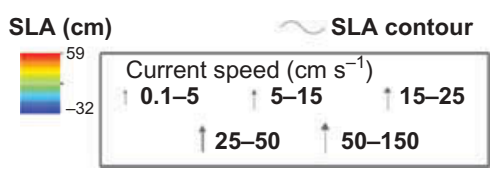

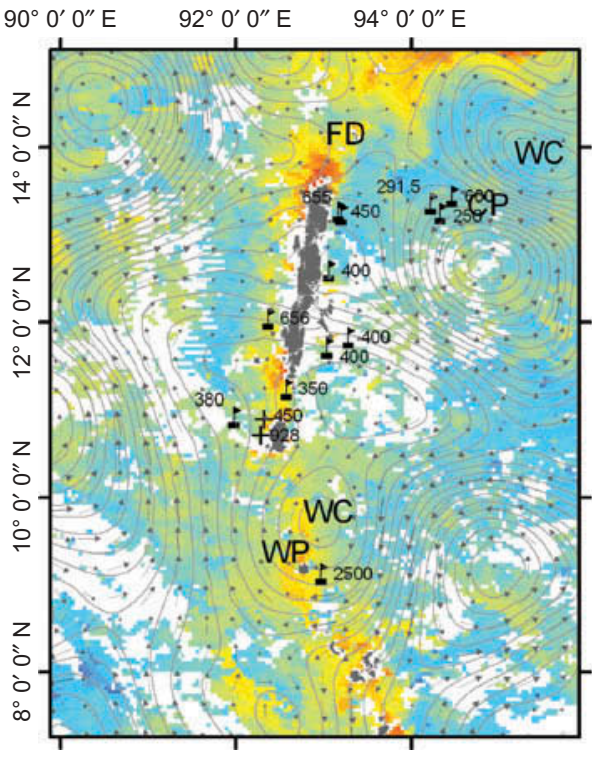

(b)

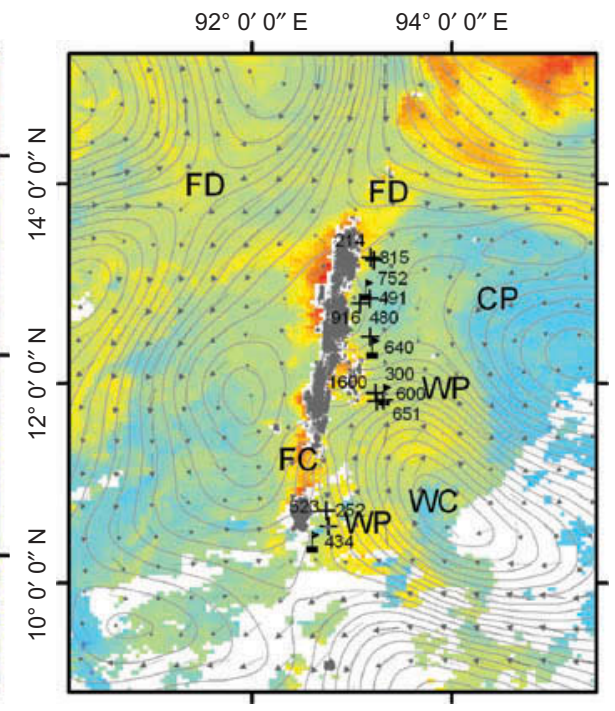

$(d)$

Fishing location and gear used Chlorophyll $\left(\mathrm{mg} \mathrm{m}^{-3}\right)$

+ Gillnet Figure next to

Longline fishing location

is CPUE in

kg per fishing day

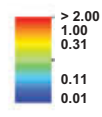

Figure 4. Sea level anomaly $((a)$ and $(c))$ and corresponding chlorophyll maps $((b)$ and $(d))$ showing increase in chlorophyll at eddy zones FD and WP.

The mean CPUEs of different gears at eddy zones were significantly different $(p<0.0001)$ (Table 3). Pairwise analysis shows that CPUE at eddy zones FD, CC, WP, and WC did not differ significantly $(p>0.01)$ from each other but had higher CPUEs than 


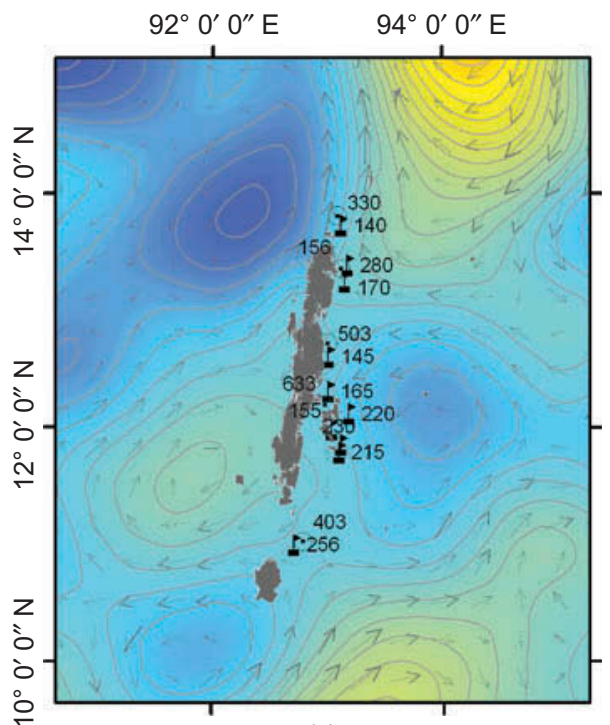

(a)

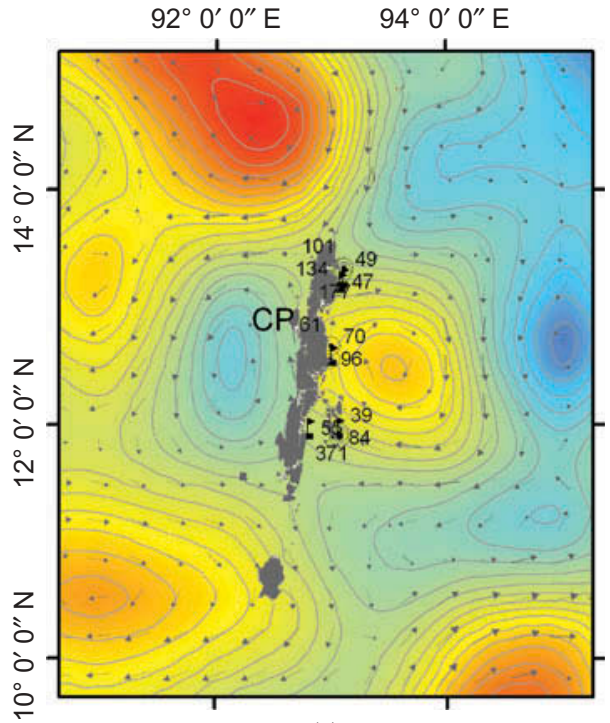

$(c)$

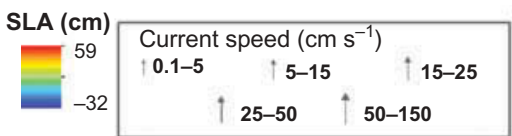

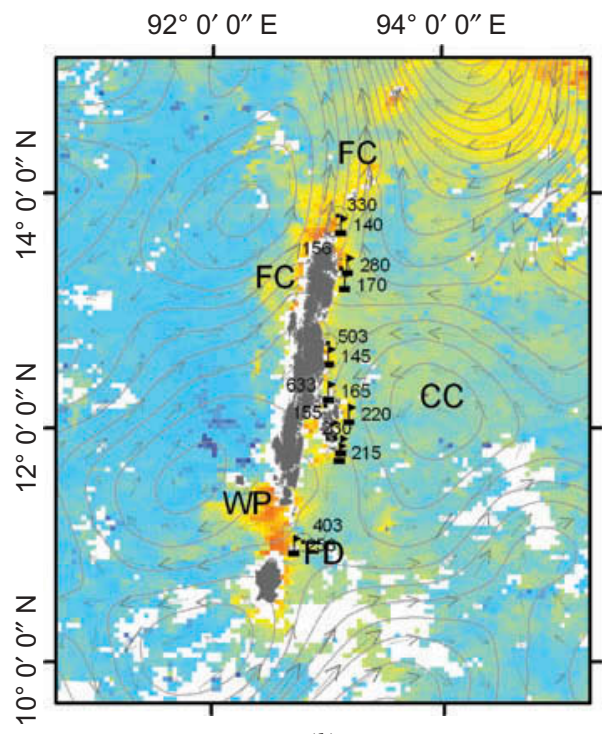

(b)

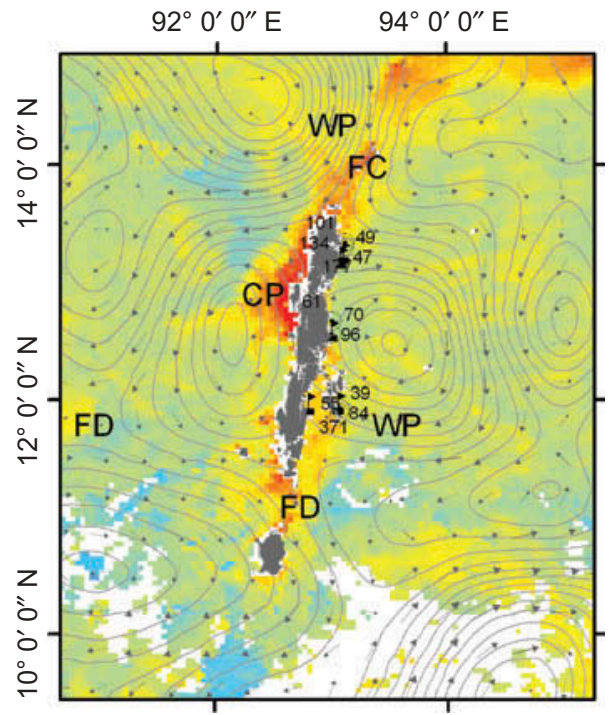

(d)

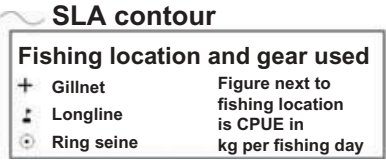

Chlorophyll $\left(\mathrm{mg} \mathrm{m}^{-3}\right)$

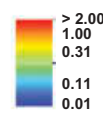

Figure 5. Sea level anomaly $((a)$ and $(c))$ and corresponding chlorophyll maps $((b)$ and $(d))$ showing increase in chlorophyll at eddy zones FC, FD, and WP.

the other eddy zones, viz. NE, CP, and WC. The eddy zones FD and WC were found to have the highest and lowest mean CPUEs, respectively (Table 4).

The variation in the mean CPUE among the various groups of fishes caught, viz. small pelagics, large pelagics, and column/demersal fishes, was found to be highly significant 
Table 3. Summary of Welch ANOVA to test the significance between the mean $\log _{10}$ CPUE values of fish catches when taken by different types of fishing gear, eddy zones, and fish groups.

\begin{tabular}{lrlll}
\hline & & \multicolumn{2}{c}{$\log _{10}$ CPUE } & \\
\cline { 3 - 4 } $\begin{array}{l}\text { Gear/eddy zone/fish } \\
\text { group }\end{array}$ & $n$ & Mean & $\begin{array}{c}\text { Standard } \\
\text { deviation }\end{array}$ & $\begin{array}{c}\text { Welch ANOVA/Unequal } \\
\text { variance } F\end{array}$ \\
\hline 1. Types of fishing gear & & & & \\
Ring seine & 143 & 2.3375 & 0.38486 & \\
Trawl & 28 & 2.1893 & 0.21748 & \\
Gillnet & 68 & 2.0814 & 0.39749 & \\
Longline & 178 & 1.9328 & 0.45765 & \\
Handline & 37 & 1.5164 & 0.30563 & \\
2. Eddy zones & & & & \\
FD & 30 & 2.3915 & 0.52541 & $F(6,106.2)=14.678, p<0.0001$ \\
CC & 26 & 2.337 & 0.36662 & \\
WP & 62 & 2.2134 & 0.29992 & \\
FC & 39 & 2.1471 & 0.43912 & \\
NE & 201 & 2.0059 & 0.48642 & \\
CP & 75 & 1.9355 & 0.43294 & \\
WC & 21 & 1.6867 & 0.27868 & \\
3. Fish species groupings & & & & \\
SP & 191 & 2.2879 & 0.38694 & $F(2,124.7)=47.545, p<0.0001$ \\
LP & 45 & 1.9645 & 0.41855 & \\
CD & 218 & 1.889 & 0.45943 & \\
\hline
\end{tabular}

Table 4. Summary of Games-Howell pairwise statistics to test the significance of difference of mean $\log _{10}$ CPUE of fish catches when taken by different types of fishing gear, eddy zones, and fish groups.

\begin{tabular}{|c|c|c|c|c|c|c|c|c|}
\hline Criteria & & Gam & es-Hov & ell prob & ability & & & \\
\hline \multirow[t]{5}{*}{ Types of fishing gear } & Ring seine & Ring seine & Trawl & Gillnet & Logline & Handline & & \\
\hline & Trawl & NS & & & & & & \\
\hline & Gillnet & $* * *$ & NS & & & & & \\
\hline & Longline & $* * *$ & $* * *$ & NS & & & & \\
\hline & Handline & $* * *$ & $* * *$ & $* * *$ & $* * *$ & - & & \\
\hline \multirow[t]{7}{*}{$\begin{array}{l}\text { Different eddy zones at } \\
\text { fishing locations }\end{array}$} & FD & FD & $\mathrm{CC}$ & WP & FC & NE & $\mathrm{CP}$ & WC \\
\hline & $\mathrm{CC}$ & NS & & & & & & \\
\hline & WP & NS & NS & & & & & \\
\hline & $\mathrm{FC}$ & NS & NS & NS & & & & \\
\hline & NE & $* *$ & $* *$ & $* *$ & NS & & & \\
\hline & $\mathrm{CP}$ & $* *$ & $* *$ & $* * *$ & NS & NS & & \\
\hline & WC & $* * *$ & $* * *$ & $* * *$ & $* * *$ & $* *$ & $*$ & - \\
\hline \multirow[t]{4}{*}{ Fish species grouping } & & SP & LP & $\mathrm{CD}$ & & & & \\
\hline & SP & & & & & & & \\
\hline & LP & $* * *$ & & & & & & \\
\hline & $\mathrm{CD}$ & $* * *$ & NS & - & & & & \\
\hline
\end{tabular}

Note: NS, not significant $(5 \%$ level); *significant $(p<0.05)$; **highly significant $(p<0.01)$; ***very highly significant $(p<0.001)$. 
$(p<0.0001)$ (Table 3). The pairwise analysis showed that the mean CPUE of small pelagics was significantly $(p<0.0001)$ higher than that of other groups (Table 4$)$.

\subsection{Effect of eddy on the performance of different fishing gears}

The effects of eddy zones on the CPUE of three fishing gears, viz. longline, ring seine, and gillnet, were analysed. The mean CPUE of longline catches varied significantly $(p<0.001)$ between various eddy zones (Table 5). The mean CPUE of longline was the highest in WP and was significantly $(p<0001)$ higher in WP, FC, CC, and CP than in NE and WC (Table 6).

The mean CPUE of ring seine at different eddy zones was found to vary significantly $(p<0.001)$ (Table 5). The mean CPUE of ring seine in FD, CC, and NE zones was found to be significantly $(p<0.001)$ higher than WP, FC, CP, and WC zones, while it was the highest in the FD zone (Table 6).

Analysis of the gillnet catches across the eddy zones showed that there was no significant $(p>0.01)$ difference in the mean CPUE of gillnets among different eddy zones.

\subsection{Effect of eddy on different group of fishes}

The effects of eddies on the catch of various groups of fish, viz. small pelagics, large pelagics, and column/demersal fish, were statistically analysed. The mean CPUE for the small pelagic fish was found to vary significantly $(p<0.001)$ in different eddy zones (Table 5) and was the highest in the FD zone and lowest in the WP zone. FD and CC zones showed significantly $(p<0.001)$ higher mean CPUE than the NE, FC, WP, CP, and WC zones (Table 6).

The mean CPUE for the large pelagic fish at different eddy zones was significantly different $(p<0.001)$ (Table 5). The FD, CC, and WP zones had significantly $(p<0.001)$ higher CPUE than NE, CP, and FC zones, with FD zone recording the highest mean CPUE (Table 6).

The study showed that there was a significant $(p<0.001)$ difference in the mean CPUE of column/demersal fish groups in different eddy zones (Table 5) and was significantly $(p<0.001)$ higher in WP, CC, and FC zones than in CP, FD, NE, and WC (Table 6).

\section{Discussion}

\subsection{General circulation, eddy formation, and upwelling in the seas around the ANI}

The ANI are a chain of islands of volcanic origin and extend from $7^{\circ} \mathrm{N}$ off the coast of Sumatra, Indonesia, to $14^{\circ} \mathrm{N}$ near Myanmar. Being an archipelago, the islands have a very narrow continental shelf bordering the islands, and the water depth increases rapidly with distance from the shore. The major features of circulation in the Andaman Sea have been described in a few works, a northeast shelf-break coastal current, an eddy and subsurface jet near the South Preparis Channel, and an eastward countercurrent extending from $80^{\circ} \mathrm{E}$ to the eastern boundary (Hacker et al. 1998); topography-induced internal waves and their mixing in the region (Li, Peng, and Zeng 2012); and general circulation in the Andaman Sea caused by semi-diurnal tides, heat flux, and alternating winds during the southwest and northeast monsoons prevalent in the region (Rizal et al. 2012). Although 
Table 5. Summary of Welch ANOVA statistics to test the significance between the mean $\log _{10}$ CPUE values of catches taken by popular fishing gears and of major fish groups at different eddy zone locations.

\begin{tabular}{|c|c|c|c|c|}
\hline & \multirow[b]{2}{*}{$n$} & \multicolumn{2}{|c|}{$\log _{10} \mathrm{CPUE}$} & \multirow[b]{2}{*}{ Welch ANOVA/Unequal variance $F$} \\
\hline & & Mean & Standard deviation & \\
\hline \multicolumn{5}{|c|}{ Eddy zones at catches taken by longline } \\
\hline WP & 21 & 2.2059 & 0.35935 & \multirow{7}{*}{$\begin{array}{l}F(6,31.055)=4.464, p=0.002 \\
\text { Longline mean } 1.9\end{array}$} \\
\hline FC & 16 & 2.1141 & 0.46189 & \\
\hline $\mathbf{C C}$ & 6 & 2.025 & 0.43712 & \\
\hline $\mathbf{C P}$ & 39 & 1.9146 & 0.49068 & \\
\hline NE & 76 & 1.8754 & 0.44442 & \\
\hline FD & 7 & 1.7294 & 0.66216 & \\
\hline WC & 13 & 1.7255 & 0.20109 & \\
\hline \multicolumn{5}{|c|}{ Eddy zones at catches taken by ring seine } \\
\hline FD & 16 & 2.6233 & 0.26884 & \multirow{7}{*}{$\begin{array}{l}F(6,15.7)=11.378, p=0.0001 \\
\quad \text { Ring seine mean } 2.335\end{array}$} \\
\hline $\mathbf{C C}$ & 14 & 2.4884 & 0.24577 & \\
\hline NE & 54 & 2.3448 & 0.44224 & \\
\hline WP & 22 & 2.2662 & 0.28668 & \\
\hline FC & 19 & 2.2273 & 0.39822 & \\
\hline CP & 16 & 2.1928 & 0.29265 & \\
\hline WC & 2 & 1.7825 & 0.1059 & \\
\hline \multicolumn{5}{|c|}{ Eddy zones at catches taken by gillnet } \\
\hline FD & 4 & 2.5562 & 0.23986 & \multirow{6}{*}{$\begin{array}{l}F(5,61)=1.936, p=0.101 \\
\text { Gillnet mean } 2.08\end{array}$} \\
\hline FC & 2 & 2.2319 & 0.64176 & \\
\hline CC & 3 & 2.2025 & 0.55239 & \\
\hline WP & 16 & 2.1103 & 0.22664 & \\
\hline NE & 37 & 2.0473 & 0.43276 & \\
\hline CP & 5 & 1.8041 & 0.27401 & \\
\hline \multicolumn{5}{|c|}{ Eddy zones where major catches were column-demersal fish } \\
\hline WP & 21 & 2.1952 & 0.36454 & \multirow[t]{7}{*}{$F(6,39.2)=5.674, p<0.001$} \\
\hline $\mathrm{CC}$ & 9 & 2.1759 & 0.42227 & \\
\hline FC & 17 & 2.1202 & 0.41517 & \\
\hline CP & 49 & 1.8721 & 0.46005 & \\
\hline FD & 8 & 1.8703 & 0.72712 & \\
\hline NE & 97 & 1.8052 & 0.43832 & \\
\hline WC & 17 & 1.6657 & 0.30546 & \\
\hline \multicolumn{5}{|c|}{ Eddy zones where major catch was small pelagics } \\
\hline FD & 18 & 2.6258 & 0.25273 & \multirow[t]{7}{*}{$F(6,29.8)=19.995, p<0.001$} \\
\hline CC & 15 & 2.4361 & 0.33292 & \\
\hline NE & 81 & 2.2756 & 0.433 & \\
\hline FC & 20 & 2.2503 & 0.40092 & \\
\hline WP & 36 & 2.2123 & 0.26889 & \\
\hline CP & 18 & 2.156 & 0.30281 & \\
\hline WC & 3 & 1.8013 & 0.08165 & \\
\hline \multicolumn{5}{|c|}{ Eddy zones where major catch was large pelagics } \\
\hline FD & 4 & 2.3794 & 0.13757 & \multirow[t]{6}{*}{$F(5,8.29)=135.6, p<0.001$} \\
\hline $\mathrm{CC}$ & 2 & 2.3187 & 0.02505 & \\
\hline WP & 5 & 2.2983 & 0.25281 & \\
\hline NE & 23 & 1.9023 & 0.41731 & \\
\hline CP & 8 & 1.8271 & 0.3753 & \\
\hline FC & 2 & 1.3443 & 0.03968 & \\
\hline
\end{tabular}


Table 6. Summary of Games-Howell pairwise statistics to test the significance of difference of mean $\log _{10}$ CPUE values at different eddy zone locations of catches taken by popular types of fishing gear and fish groups.

\begin{tabular}{|c|c|c|c|c|c|c|c|c|}
\hline \multirow{2}{*}{$\frac{\text { Criteria }}{\text { Eddy zones at catches taken by longlines }}$} & \multirow[b]{3}{*}{ WP } & & \multicolumn{6}{|c|}{ Games-Howell probability } \\
\hline & & WP & FC & $\mathbf{C C}$ & $\mathbf{C P}$ & NE & FD & WC \\
\hline & & & & & & & & \\
\hline & FC & NS & & & & & & \\
\hline & CL & NS & NS & NS & & & & \\
\hline & NE & * & NS & NS & NS & & & \\
\hline & FD & NS & NS & NS & NS & NS & & \\
\hline & WC & $* * *$ & NS & NS & NS & NS & NS & \\
\hline \multirow[t]{8}{*}{ Eddy zones at catches taken by ring seines } & & FD & $\mathbf{C C}$ & NE & WP & FC & $\mathbf{C P}$ & WC \\
\hline & FD & & & & & & & \\
\hline & $\mathbf{C C}$ & NS & & & & & & \\
\hline & NE & NS & NS & & & & & \\
\hline & WP & $* *$ & NS & NS & & & & \\
\hline & FC & $*$ & NS & NS & NS & & & \\
\hline & $\mathbf{C P}$ & $* *$ & NS & NS & NS & NS & & \\
\hline & WC & $*$ & $*$ & NS & NS & NS & NS & \\
\hline \multirow{8}{*}{$\begin{array}{l}\text { Eddy zones at catches where major catches } \\
\text { were column-demersal }\end{array}$} & & WP & $\mathbf{C C}$ & FC & $\mathbf{C P}$ & FD & NE & WC \\
\hline & WP & & & & & & & \\
\hline & CC & NS & & & & & & \\
\hline & FC & NS & NS & & & & & \\
\hline & CP & $*$ & NS & NS & & & & \\
\hline & FD & NS & NS & NS & NS & & & \\
\hline & $\mathbf{N E}$ & $* *$ & NS & NS & NS & NS & & \\
\hline & WC & $* * *$ & NS & $*$ & NS & NS & NS & \\
\hline \multirow{7}{*}{$\begin{array}{l}\text { Eddy zones at catches where major catch was } \\
\text { small pelagics }\end{array}$} & FD & FD & $\mathbf{C C}$ & $\mathbf{N E}$ & FC & WP & $\mathbf{C P}$ & WC \\
\hline & CC & NS & & & & & & \\
\hline & NE & $* *$ & NS & & & & & \\
\hline & FC & $*$ & NS & NS & & & & \\
\hline & WP & $* * *$ & NS & NS & NS & & & \\
\hline & CP & $* * *$ & NS & NS & NS & NS & & \\
\hline & WC & $* * *$ & $* * *$ & $* *$ & $* *$ & $* *$ & $*$ & \\
\hline \multirow{7}{*}{$\begin{array}{l}\text { Eddy zones at catches where major catch was } \\
\text { large pelagics }\end{array}$} & & FD & $\mathbf{C C}$ & WP & NE & CP & FC & \\
\hline & FD & & & & & & & \\
\hline & CC & NS & & & & & & \\
\hline & WP & NS & NS & & & & & \\
\hline & NE & $* *$ & $* *$ & NS & & & & \\
\hline & CP & $*$ & NS & NS & NS & & & \\
\hline & FC & $* *$ & $* *$ & $* *$ & $* * *$ & NS & & \\
\hline
\end{tabular}

Note: NS, not significant $(5 \%$ level); *significant $(p<0.05)$; **highly significant $(p<0.01)$, ***very highly significant $(p<0.001)$.

there is no major riverine input from the islands, the run-off from the Irrawady river in Myanmar, to the north of the ANI, is significant enough to influence the coastal productivity in the northern regions of the islands. The islands receive high rainfall from both monsoons (average rainfall of $3100 \mathrm{~mm}$ ), and the run-off from the forests and mangroves is known to be the source of nutrients for the shallow coastal waters (Roy and George 2010). The Andaman Sea and northern BoB are strongly affected by run-off from the 
Irrawady-Salween system, with outflows ranging from $28.3 \times 10^{9} \mathrm{~m}^{3}$ per month during winter to $307.7 \times 10^{9} \mathrm{~m}^{3}$ per month during summer, and the effect of the run-off is seen extending up to $90^{\circ} \mathrm{E}$ and $9^{\circ} \mathrm{N}$ (Varkey, Murty, and Sur Yanarayana 1996). In the current study, eddies were frequently observed off the Landfall islands, at the northern tip of the ANI. They were restricted to the regions northeast and northwest of the Landfall islands by the shallowness of the ridge connecting the northern part of the ANI with the Myanmar mainland. These eddies may aid to drive the run-off from Irrrawady towards the ANI or into the northeastern region of the Andaman Sea. An example of this can be seen in Figures $4(c)$ and 5(c), where an anticyclonic eddy to the northwest of ANI induces a plume of increased chlorophyll (seen in Figures $4(d)$ and $5(d)$ ), which extends from the Irrawady delta to the northern tip of the ANI. The effects of this run-off on the primary and secondary productivity in the island's waters needs to be further studied.

During the formation of cyclonic eddies in the northern hemisphere, the anticlockwise rotation drives the surface Ekman transport from the centre to the periphery, resulting in the negative anomaly at the central region. Vertical Ekman pumping lifts the thermocline at the centre of the eddy, breaks the stratification to bring up the cool nutrient rich waters to the euphotic zone, and the favourable conditions created by the presence of light and nutrient in the otherwise nutrient-limited mixed layer triggers the primary productivity (Bakun 2006; Kimura, Nakata, and Okazaki 2000; Sánchez-Velasco et al. 2013). The upwelled water at the centre of the cyclonic eddies is transported to the periphery where it downwells. The downwelling zone with nutrient-depleted waters and increased mixed layer depth reduces plankton abundance and lowers the primary productivity. Anticyclonic eddies have upwelling with increased primary productivity at the periphery and downwelling with lower primary productivity at the core. As it is the secondary circulation in the eddy that is responsible for conversion of physical energy into biological productivity, the extent and intensity of downwelling and upwelling in the eddies is governed by the age of the eddy and whether it is spinning up under frictional forcing or decaying as a free eddy (Bakun 2006). Weekly composite maps of chlorophyll overlaid with the MSLA contours show increase in chlorophyll at the periphery of anticyclonic WP (Figures $4(b), 4(d)$, and $5(d)$ ) and at the core of cyclonic (CC) eddies (Figure 5(b)), where upwelling is expected. Analysis of SLA maps indicated that the seas around ANI have frequent eddy formation, with the predominance of anticyclonic eddies. The interactions between two anticyclonic eddies were seen as areas of divergence (FD) (Figures 4(b), $4(d), 5(b)$, and $5(d)$ ), and vertical transport in these areas resulted in higher chlorophyll. Interactions between anticyclonic and cyclonic eddies cause regions of high MSLA gradient (FC) (Figures $4(d), 5(b)$, and $5(d)$ ), within which there was an increase in chlorophyll. The core of anticyclonic (WC) and periphery of cyclonic (CP) (Figures 4(b) and $4(d)$ ) eddies are not showing changes in chlorophyll. Although an increase in chlorophyll was noticed at the favourable areas, SST changes were not accompanying the areas of upwelling as also observed by Buranapratheprat et al. (2010).

Studies on the generation and effects of eddies are few in the BoB (Nuncio and Prasanna-Kumar 2012) and rare in the Andaman Sea (Buranapratheprat et al. 2010), although their presence has been reported (Gopalan et al. 2000; Prasanna-Kumar, Nuncio, and Narvekar 2004; Babu, Prasanna-Kumar, and Rao 1991) using remotesensing and in situ observations. In the $\mathrm{BoB}$, coastal eddies enhance the productivity despite the basin being stratified due to high run-off from rivers and low evaporation (Nuncio and Prasanna-Kumar 2012; Prasanna-Kumar, Nuncio, and Narvekar 2004). Surface and subsurface eddies pumped nutrients to the oligotrophic surface layer to increase productivity by two to eight fold along the western boundary of BoB 
(Prasanna-Kumar et al. 2002, 2007). The Andaman Sea is low in nutrients, especially dissolved inorganic nitrogen - which is purported to be the limiting nutrient (Buranapratheprat et al. 2010). In the absence of major currents in the region, cyclonic mesoscale eddies provide nutrients to the upper photic zone driven by a weak upwelling (Buranapratheprat et al. 2010).

The coastal and fishing areas around the ANI were under frequent cloud cover, obscuring the chlorophyll and SST maps. The open ocean had relatively less cloud cover where the plankton productivity could be correlated to the eddy upwelling. The islands have a narrow shelf area (ANDFISH 2005) with a well-developed pelagic fishery. The narrow continental shelf results in the eddy activity closer to the islands in areas which are the fishing grounds. Large numbers of catch locations (56\% of total catches) are located in areas of eddy activity. Figures 6 and 7 indicate the catch locations that occurred at the different eddy zones.

\subsection{CPUE by fishing gear}

Ring seine has the highest mean CPUE followed by trawl, gillnet, hook and line, and handline. The variation in the mean CPUE among different fishing gears could be attributed to the difference in the nature of fishing, viz. active fishing (seine and trawl) and passive fishing (gillnet, longline, and handline) and the habit and habitat of fishes targeted by different gears. Ring seine targets smaller pelagic fishes with a shoaling behaviour, which results in large hauls. Trawl is a non-selective gear, actively targeting column and benthic fish resulting in large hauls of mixed sizes of fish. Gillnet, longline, and handline are passive and selective fishing gear which target individual fish by size as governed by mesh size, hook size, and bait, respectively.

\subsection{Effect of eddy on CPUE}

Catches from different eddy zones clearly show that the favourable processes such as upwelling at WP and $\mathrm{CC}$ zones and frontal mixing at $\mathrm{FC}$ and $\mathrm{FD}$ zones support higher mean CPUE. The eddy zones $\mathrm{CP}$ and $\mathrm{WC}$ are considered less favourable zones. NE zones show significantly lower mean CPUE than favourable eddy zones.

\subsection{Effect of eddy on performance of fishing gear}

\subsubsection{Longline}

In the longline catch, WP, FC, CC, and CP zones recorded significantly high mean CPUE, which could be attributed to higher forage availability and optimal environmental conditions. Predatory fishes targeted by longline are attracted by the forage availability and the unique conditions created at each eddy zone. The WP zone is located at the periphery of an anticyclonic eddy or meander interface with increase in chlorophyll. Mizobata et al. (2002) and Bakun (2006) reported that CC eddy zones are usually productive. The FC zone is a high-gradient area between cyclonic and anticyclonic eddy pairs. The confluence zones between positive and negative anomalies are areas of upwelling with nutrient-rich water, thus supporting high primary production and accumulation of zooplankton and micro-nekton, which serve as forage for cetaceans (Davis et al. 2002). Foraging activity of grey-headed Albatross was concentrated at the edges of the interface between positive and negative anomalies (Nel et al. 2001). Longlines in the ANI target larger pelagics, which 


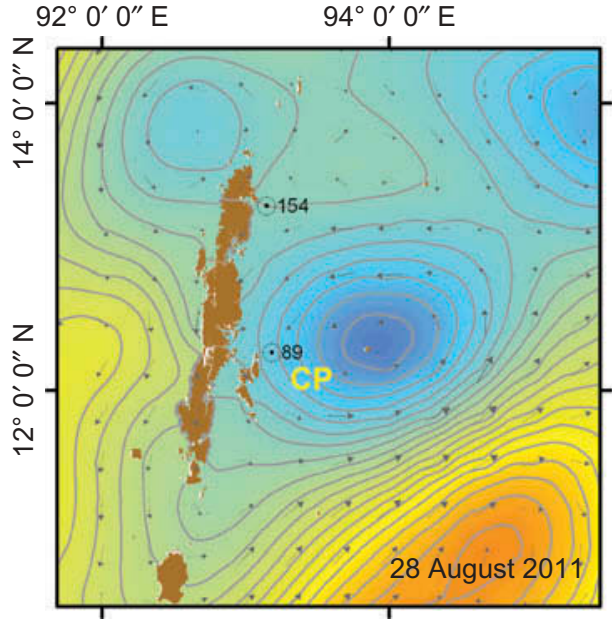

(a)

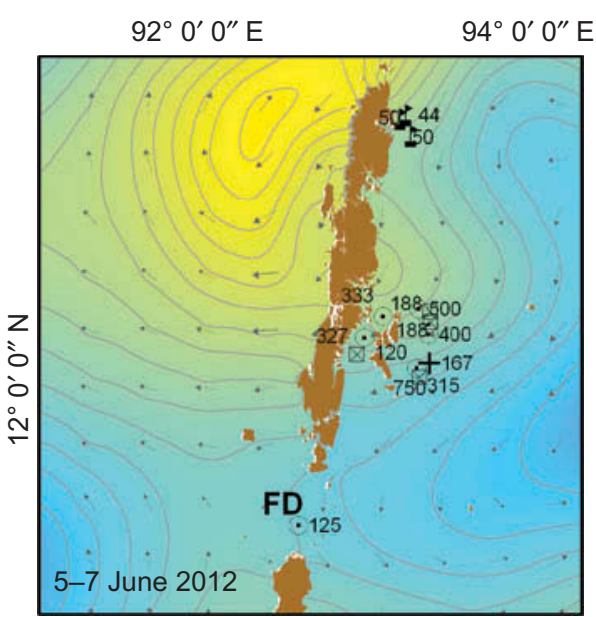

(c)

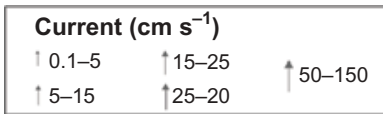

$92^{\circ} 0^{\prime} 0^{\prime \prime} \mathrm{E}$

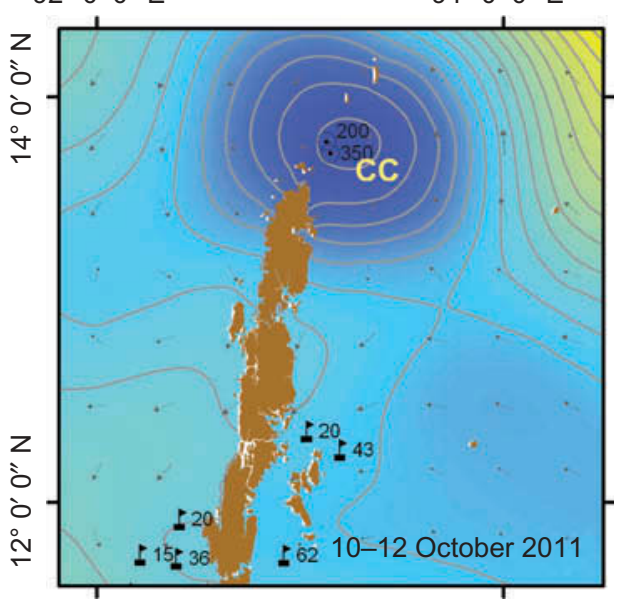

(b)

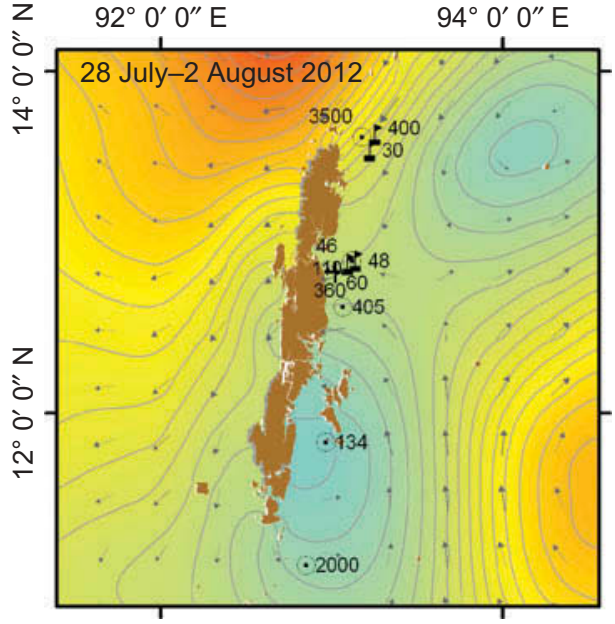

$(d)$

\begin{tabular}{|l|} 
SLA Contour \\
\begin{tabular}{|ll|}
\hline Fishing location and gear used \\
+ Gillnet & Figure next to \\
L Longline & fishing location \\
5 Ring seine & is CPUE in \\
Trawler & kg per fishing day \\
\hline
\end{tabular}
\end{tabular}

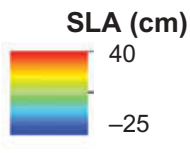

Figure 6. Sea level anomaly maps showing fish catch from different eddy zones.

are predatory in habit, feeding mostly on forage accumulated in productive areas. Many earlier studies have reported similar variation in the catch of larger pelagics in various eddy zones. Skipjack was found in the frontal zone and anticyclonic eddies where warm and cold tongues meet (Laevastu and Rosa 1963). Tunas are visual predators feeding at the frontal boundaries where prey and environmental conditions are optimum (Ramos et al. 1996). Similarly, blue marlin catches were influenced by temperature variations at fronts and prey availability (Seki, Lumpkin, and Flament 2002). Ocean fronts had effects on the CPUE of swordfish (Podestá, Browder, and Hoey 1993) and Albacore tuna (Laurs, 


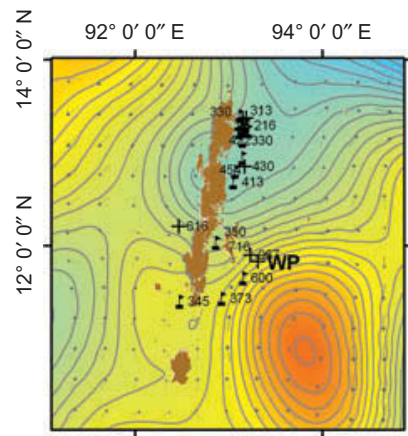

(a)

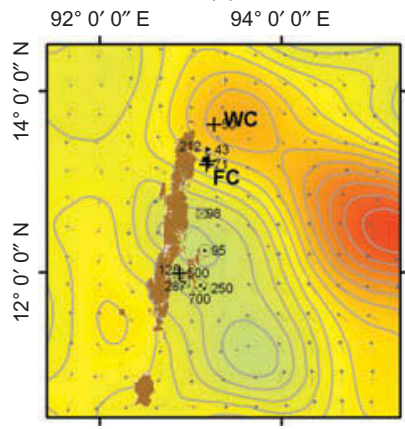

$(d)$

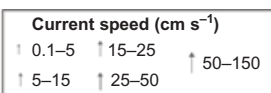

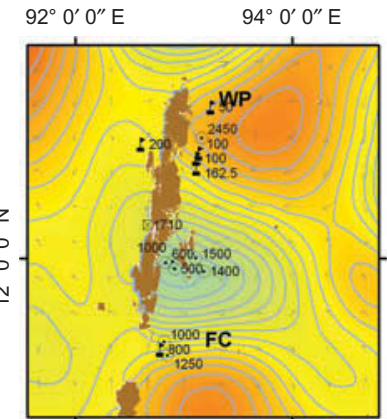

(b)

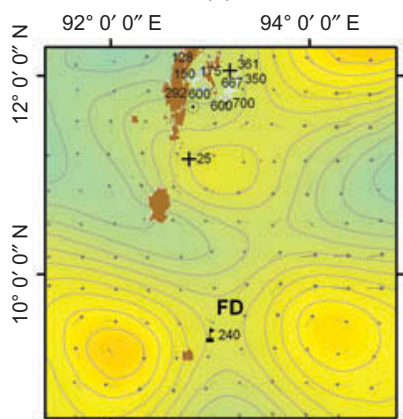

(e)

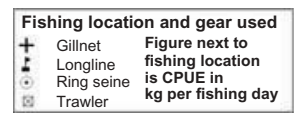

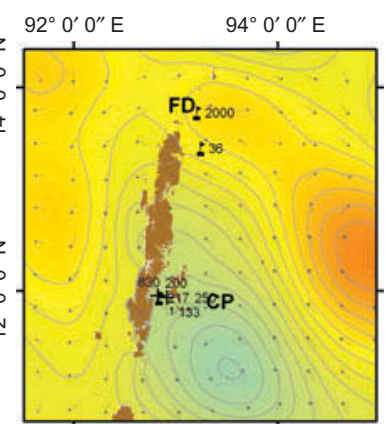

(c)

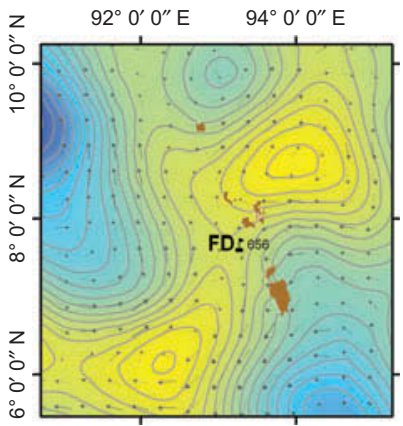

$(f)$

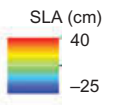

Figure 7. Sea level anomaly maps showing fish catch from different eddy zones.

Fiedler, and Montgomery 1984) caught by longline. Convergent fronts attract predatory fish by the physical accumulation of forage species (Fiedler and Bernard 1987; Olson et al. 1994). Eddy upwelling at WP, CC, and FC zones in the ANI is associated with increase in chlorophyll. CP zones show downwelling and do not trigger primary productivity. However, unique oceanographic conditions created by cyclonic eddy close to the coast physically limit the movements of large predators such as blue marlin and increase their catch (Seki, Lumpkin, and Flament 2002). The occurrence of cyclonic eddies close to the ANI coast may cause similar conditions at CP zones (Figures 5(c) and $(d)$ ). The significantly lower mean CPUE at NE and WC can be due to lack of forage accumulation.

\subsubsection{Ring seine}

Mean CPUEs of ring seine are significantly high in FD, CC, and NE eddy zones and low in WC. The FD zones include region between anticyclonic and anticyclonic eddy pairs. Anticyclonic eddies have convergence and downwelling at the core (Mizobata et al. 2002; Bakun 2006) and upwelling at the periphery. In the ANI, anticyclonic eddy pairs were observed frequently (Figures 7(c), (e), and $(f)$ ), and concurrent chlorophyll maps indicated an increase in chlorophyll levels (Figures $4(d)$ and $5(d)$ ) in the zones between such eddy pairs. With upwelling at the periphery of both eddies, a zone of upwelling and divergence is created in the common intervening area with an increase in chlorophyll attracting planktivorous pelagic fish. Upwelling and an increase in chlorophyll are seen at the 
core of cyclonic eddies (CC). Passive uplifting following the upwelling increases the concentration of larval and juvenile fish at the core of the cold core eddy (cyclonic) (Nishimoto and Washburn 2002). At such zones, the ring seine primarily targets small pelagic planktivorous fishes such as sardine, anchovy, and mackerel.

It is interesting to note that the eddy zones WP and FC favour longline over ring seine in terms of better CPUE, while the same is reversed in FD and NE zones. The apparent differences could be attributed to the intricacies associated with the fishing method, skill and traditional knowledge of the fishers, and biology of the species involved, which need further examination of eddy structures and fishery at finer scales.

\subsubsection{Gillnet}

Mean CPUE of gillnet did not vary significantly $(p>0.001)$ among the eddy zones, which could be due to the smaller number of catch records. The method of operation of the three types of fishing gear analysed above is different. Ring seiners target the shoaling/schooling fish, while the longliners locate the fishing ground based on the colour and turbidity of the water. The gillnets are barrier nets deployed in the dark relying on chance encounters of the fish with the net.

\subsection{Effect of eddy on different groups of fishes}

\subsubsection{Pelagics}

The study showed that the smaller pelagics tend to concentrate more in the FD and CC zones, and are caught by smaller mesh-sized ring seine and gillnet. The larger pelagics congregate in the FD, CC, and WP zones and are caught by longline, large-meshed gillnet, ring seine, and handline. It is also observed in the case of ring seine that the FD and $\mathrm{CC}$ areas are favourable for small pelagic and large pelagic groups. The central regions of cyclonic eddies (CC) are known to have an upwelling of nutrient-rich water and, consequently, have high primary productivity to support adult phytoplankton feeders and larval stages (Yoder et al. 1981). The smaller pelagic group considered here comprises primarily plankton feeders. Anticyclonic eddies have upwelling zones in their peripheries, and when two such eddies occur in proximity, the zone in between them - the FD zone is a region of upwelling and divergence formed in between anticyclonic eddy pairs. Enhanced primary productivity and accumulation of forage in the upwelling areas at the anticyclonic eddy periphery (WP) attract seabirds (Hyrenbach et al. 2006) and loggerhead turtles (Polovina et al. 2006). Concentration of subsurface prey accessible at the edge of the shallow-foraging depth is considered suitable for loggerheads (Polovina et al. 2006). The accumulation of forage at the WP eddy zone is reported. But, forage accumulation at the intervening areas between anticyclonic pairs (FD) is not much explored. However, eddy pairs were sighted with an increase in chlorophyll in the FD zone in the study area. This increased plankton productivity at FD eddy zones seemingly attracts smaller pelagic fishes. The higher catches of smaller pelagics in the CC and FD zones seem to be driven primarily by the availability of plankton. While plankton availability may attract the small pelagics to the upwelling zones (FD, CC, and WP), lower CPUE in the WP zone in comparison to the other two zones might be due to higher current speed, as it lies in the eddy periphery. The increase in CPUE of large pelagic fishes in the CC and FD zones could be directly related to the accumulation of prey and in the WP zone to their ability to exploit available prey as they are strong swimmers. The distribution of large pelagics is 
determined by the accumulation of prey and controlled by environmental factors such as temperature (Stretta 1991; Brill 1996; Block et al. 1997), mixed layer depth, gradient and depth of thermocline, and dissolved oxygen concentration (Brill 1994). The aggregation of small pelagics is determined by the abundance and density of prey (plankton) and controlled by temperature, turbidity, and changes in current speed (Bertrand et al. 2002; Freon et al. 2005).

\subsubsection{Column/demersals}

The column and demersal group comprises larger lutjanids, nemipterids, lethrinids, and carangids that are caught by longline, handline, and trawl. Most of these fishes are large carnivores/omnivores with restricted feeding migration compared to the pelagic fishes. Their feeding habits are different from the planktivorous small pelagics or foraging large pelagics, as they are not dependent on plankton blooms and are mostly localized feeders. However, the mean CPUE of column/demersal group is higher at WP, CC, and FC eddy zones, which are the regions of upwelling (WP and $\mathrm{CC}$ ) or convergence (FC), which could be attributed to enhanced forage due to the favourable eddy zones in the habitats. The bio-physical link seen in the eddies extends up to the higher trophic meso-pelagic and deep water fish from phyto- and zooplankton and krill (Godø et al. 2012). The eddymediated productivity seems to increase their availability to the fishery.

\section{Conclusions}

The oceanographic condition of the fishing grounds of the ANI with reference to mesoscale eddy is studied in detail for the first time. The study shows a strong link between the eddy activity and performance of the fishery. The mean CPUE was observed to vary significantly $(p<0.001)$ among the different eddy zones. It was found that the eddy effect was highly significant $(p<0.0001)$ on the various types of fishing gears and the types of fishes caught, viz. small pelagics, large pelagics, and column/demersal fishes. The study successfully demonstrates the relationship between the efficiency of the major fishing gear and fish groups and the zones of mesoscale eddies derived from satellite altimetry. The relationship is a key link in the operational use of satellite altimetry for providing fishery advice to fishermen. Currently, the PFZ advisories for the islands are based on satellite-based chlorophyll and SST data, for which cloud-free data are prerequisites. As the eddy zones can be determined using satellite altimetry irrespective of the cloud cover, the results of the current study testify the possibility of integrating SSH into the existing protocol for PFZ delineation and thus pave the way for round-the-year dissemination of advisories. It is hoped that the approach would enormously benefit the fishers in ANI, where the rate of exploitation is less than $20 \%$ of the potential and the satellite-based identification of fishing grounds is constrained by cloud cover over the islands for about eight months a year.

\section{Acknowledgements}

This study is a component of the science investigations carried out by the authors as a part of SARAL (Satellite with Argos and ALtiKa)/AltiKa science team. The authors would like to thank AVISO of CNES (Centre National d'Etudes Spatiales) for altimetry data, PO.DAAC - NASA for SST and OceanColor - NASA for chlorophyll data. The support from the Director, Central Agricultural Research Institute (CARI), in conducting the research study is thankfully acknowledged. Constant support and encouragement from the Director, National Remote Sensing Centre 
(NRSC), is acknowledged. The authors thank Deemat C. Mathews for his support in the statistical analysis of catch data.

\section{References}

ANDFISH. 2005. "Roadmap for development of fisheries in the Andaman \& Nicobar Islands." Fisheries Division, Indian Council of Agricultural Research, June 2005, 90 pp.

Babu, M. T., S. Prasanna-Kumar, and D. P. Rao. 1991. "A Subsurface Cyclonic Eddy in the Bay of Bengal." Journal of Marine Research 49: 404-410.

Bakun, A. 2006. "Fronts and Eddies as Key Structures in the Habitat of Marine Fish Larvae: Opportunity, Adaptive Response and Competitive Advantage." Scientia Marina 70 (S2): $105-122$.

Bertrand, A., E. Josse, P. Bach, P. Gros, and L. Dagorn. 2002. "Hydrological and Trophic Characteristics of Tuna Habitat: Consequences on Tuna Distribution and Longline Catchability." Canadian Journal of Fisheries and Aquatic Sciences 59: 1002-1013. doi:10.1139/f02-073.

Block, B. A., J. E. Keen, B. Castillo, H. Dewar, E. V. Freund, D. J. Marcinek, R. W. Brill, and C. Farwell. 1997. "Environmental Preferences of Yellowfin Tuna (Thunnus albacares) at the Northern Extent of Its Range." Marine Biology 130: 119-132. doi:10.1007/s002270050231.

Brill, R. W. 1994. "A Review of Temperature and Oxygen Tolerance Studies of Tunas Pertinent to Fisheries Oceanography, Movement Models and Stock Assessments." Fisheries Oceanography 3: 204-216. doi:10.1111/j.1365-2419.1994.tb00098.x.

Brill, R. W. 1996. "Selective Advantages Conferred by the High Performance Physiology of Tunas, Billfishes and Dolphin Fish." Comparative Biochemistry and Physiology Part A: Physiology 113 (1): 3-15. doi:10.1016/0300-9629(95)02064-0.

Buranapratheprat, A., P. Laongmanee, N. Sukramongkol, R. Prommas, S. Promjinda, and T. Yanagi. 2010. "Upwelling Induced by Mesoscale Cyclonic Eddies in the Andaman Sea." Coastal Marine Science 34 (1): 68-73.

Chaigneau, A., N. Dominguez, G. Eldin, L. Vasquez, R. Flores, C. Grados, and E. Echevin. 2013. "Near-Coastal Circulation in the Northern Humboldt Current System from Shipboard ADCP Data." Journal of Geophysical Research: Oceans 118: 1-16. doi:10.1002/jgrc.20328.

Chelton, D. B., M. G. Schlax, and R. M. Samelson. 2011. "Global Observations of Nonlinear Mesoscale Eddies." Progress in Oceanography 91: 167-216. doi:10.1016/j. pocean.2011.01.002.

Chen, X., D. Pan, Y. Bai, X. He, C. A. Chen, and Z. Hao. 2013. "Episodic Phytoplankton Bloom Events in the Bay of Bengal Triggered by Multiple Forcings." Deep Sea Research Part I: Oceanographic Research Papers 73: 17-30. doi:10.1016/j.dsr.2012.11.011.

Crawford, W. R., P. J. Brickley, and A. C. Thomas. 2007. "Mesoscale Eddies Dominate Surface Phytoplankton in Northern Gulf of Alaska." Progress in Oceanography 75: 287-303. doi:10.1016/j.pocean.2007.08.016.

Davis, R. W., J. G. Ortega-Ortiz, C. A. Ribic, W. E. Evans, D. C. Biggs, P. H. Ressler, R. B. Cady, R. R. Leben, K. D. Mullin, and B. Würsig. 2002. "Cetacean Habitat in the Northern Oceanic Gulf of Mexico." Deep Sea Research Part I: Oceanographic Research Papers 49: 121-142. doi:10.1016/S0967-0637(01)00035-8.

Ducet, N., and P.-Y. Le Traon. 1999. "How Accurately Can We Map the Mesoscale Ocean Surface Variability from the Combination of T/P and ERS-1/2 Altimetric Data?" International WOCE Newsletter, no. 37: 40-43.

Fiedler, P. C., and H. J. Bernard. 1987. "Tuna Aggregation and Feeding Near Fronts Observed in Satellite Imagery." Continental Shelf Research 7: 871-881. doi:10.1016/0278-4343(87)90003-3.

Freon, P., P. Cury, L. Shannon, and C. Roy. 2005. "Sustainable Exploitation of Small Pelagic Fish Stocks Challenged by Environmental and Ecosystem Changes: A Review." Bulletin of Marine Science 76 (2): 385-462.

FSI. 2007. "National Marine Fisheries Census 2005: Union Territories of Andaman \& Nicobar and Lakshadweep Islands." New Delhi: Ministry of Agriculture, Department of Animal Husbandry, Dairying \& Fisheries, Government of India, 177.

Godø, O. R., A. Samuelsen, G. J. Macaulay, R. Patel, S. S. Hjøllo, J. Horne, S. Kaartvedt, and J. A. Johannessen. 2012. "Mesoscale Eddies Are Oases for Higher Trophic Marine Life." PLoS ONE 7 (1): e30161. doi:10.1371/journal.pone.0030161. 
Gopalan, A. K. S., V. V. Gopala Krishna, M. M. Ali, and R. Sharma. 2000. "Detection of Bay of Bengal Eddies from TOPEX and in situ Observations." Journal of Marine Research 58: 721-734. doi:10.1357/002224000321358873.

Grinson, G., P. Krishnan, S. Dam-Roy, K. Sarma, M. P. Goutham-Bharathi, M. Kaliyamoorthy, V. Krishnamurthy, and T. Srinivasa-Kumar. 2013. "Validation of Potential Fishing Zone (PFZ) Forecasts from Andaman and Nicobar Islands." Fishery Technology 50: 1-5.

Grinson, G., P. Krishnan, S. Kamal, R. Kirubasankar, M. P. Goutham-Bharathi, M. Kaliyamoorthy, V. Krishnamurthy, and T. Srinivasa-Kumar. 2011. "Integrated Potential Fishing Zone (IPFZ) Forecasts: A Promising Information and Communication Technology Tool for Promotion of Green Fishing in the Islands.” Indian Journal of Agricultural Economics 66 (3): 513-519.

Grinson, G., K. Sarma, G. Bharathi, M. Kaliyamoorthy, P. Krishnan, and R. Kirubasankar. 2014. "Efficacy of Different Modes in Disseminating Potential Fishing Zone (PFZ) Forecasts: A Case Study from Andaman and Nicobar Islands." Indian Journal Fisheries 61 (1): 84-87.

Hacker, P., E. Firing, J. Hummon, A. L. Gordon, and J. C. Kindle. 1998. "Bay of Bengal Currents during the Northeast Monsoon." Geophysical Research Letters 25 (15): 2769-2772. doi:10.1029/98GL52115.

Hyrenbach, K. D., R. R. Veit, H. Weimerskirch, and G. L. Hunt. 2006. "Seabird Associations with Mesoscale Eddies: The Subtropical Indian Ocean." Marine Ecology Progress Series 324: 271-279. doi:10.3354/meps324271.

José, Y. S., O. Aumont, E. Machu, P. Penven, C. L. Moloney, and O. Maury. 2014. "Influence of Mesoscale Eddies on Biological Production in the Mozambique Channel: Several Contrasted Examples from a Coupled Ocean-Biogeochemistry Model." Deep Sea Research Part II: Topical Studies in Oceanography 100: 79-93. doi:10.1016/j.dsr2.2013.10.018.

Kimura, S., H. Nakata, and Y. Okazaki. 2000. "Biological Production in Meso-Scale Eddies Caused by Frontal Disturbances of the Kuroshio Extension." ICES Journal of Marine Science 57 (1): 133-142. doi:10.1006/jmsc.1999.0564.

Kobayashi, D. R., I. Cheng, D. M. Parker, J. J. Polovina, N. Kamezaki, and G. H. Balazs. 2011. "Loggerhead Turtle (Caretta caretta) Movement off the Coast of Taiwan: Characterization of a Hotspot in the East China Sea and Investigation of Mesoscale Eddies." ICES Journal of Marine Science 68 (4): 707-718. doi:10.1093/icesjms/fsq185.

Kurczyn, J. A., E. Beier, M. F. Lavin, A. Chaigneau, and V. M. Godinez. 2013. "Anatomy and Evolution of a Cyclonic Mesoscale Eddy Observed in the North-Eastern Pacific TropicalSubtropical Transition Zone." Journal of Geophysical Research: Oceans 118: 1-20. doi:10.1002/2013JC009339.

Laevastu, T., and H. Rosa. 1963. "Distribution and Relative Abundance of Tunas in Relation to Their Environment." FAO Fisheries Report 6: 1835-1851.

Laurs, R. M., P. C. Fiedler, and D. R. Montgomery. 1984. "Albacore Tuna Catch Distributions Relative to Environmental Features Observed from Satellites." Deep Sea Research Particle A Oceanographic Research Papers 31: 1085-1099. doi:10.1016/0198-0149(84)90014-1.

Li, Y., S. Peng, and X. Zeng. 2012. "Observations and Simulations of the Circulation and Mixing around the Andaman-Nicobar Submarine Ridge." Atmospheric and Oceanic Science Letters 5 (4): 319-323.

Lindo-Atichati, D., F. Bringas, and G. Goni. 2013. "Loop Current Excursions and Ring Detachments during 1993-2009." International Journal of Remote Sensing 34 (14): 5042-5053. doi:10.1080/01431161.2013.787504.

Lindo-Atichati, D., F. Bringas, G. Goni, B. Muhling, F. E. Muller-Karger, and S. Habtes. 2012. "Varying Mesoscale Structures Influence Larval Fish Distribution in the Northern Gulf of Mexico." Marine Ecology Progress Series 463: 245-257. doi:10.3354/meps09860.

McGillicuddy, D. J., A. R. Robinson, D. A. Siegel, H. W. Jannasch, R. Johnson, T. D. Dickey, J. McNeil, A. F. Michaels, and A. H. Knap. 1998. "Influence of Mesoscale Eddies on New Production in the Sargasso Sea." Nature 394: 263-266. doi:10.1038/28367.

Mizobata, K., S. I. Saitoh, A. Shiomoto, T. Miyamura, N. Shiga, K. Imai, M. Toratani, Y. Kajiwara, and K. Sasaoka. 2002. "Bering Sea Cyclonic and Anticyclonic Eddies Observed during Summer 2000 and 2001." Progress in Oceanography 55: 65-75. doi:10.1016/S0079-6611(02)00070-8.

Nel, D. C., J. R. E. Lutjeharms, E. A. Pakhomov, I. J. Ansorge, P. G. Ryan, and N. T. W. Klages. 2001. "Exploitation of Mesoscale Oceanographic Features by Grey-Headed Albatross Thalassarche chrysostoma in the Southern Indian Ocean." Marine Ecology Progress Series 217: 15-26. doi:10.3354/meps217015. 
Nishimoto, M. M., and L. Washburn. 2002. "Patterns of Coastal Eddy Circulation and Abundance of Pelagic Juvenile Fish in the Santa Barbara Channel, California, USA.” Marine Ecology Progress Series 241: 183-199. doi:10.3354/meps241183.

Nuncio, M., and S. Prasanna-Kumar. 2012. "Life Cycle of Eddies along the Western Boundary of the Bay of Bengal and Their Implications." Journal of Marine Systems 94: 9-17. doi:10.1016/j. jmarsys.2011.10.002.

Olson, D. B., and R. H. Backus. 1985. "The Concentrating of Organisms at Fronts: A Cold-Water Fish and a Warm-Core Gulf Stream Ring." Journal of Marine Research 43: 113-137. doi: $10.1357 / 002224085788437325$.

Olson, D. B., G. L. Hitchcock, A. J. Mariano, C. J. Ashjian, G. Peng, R. W. Nero, and G. P. Podesta. 1994. "Life on the Edge: Marine Life and Fronts." Oceanography 7: 52-60. doi:10.5670/ oceanog.1994.03.

Podestá, G. P., J. A. Browder, and J. J. Hoey. 1993. "Exploring the Association between Swordfish Catch Rates and Thermal Fronts on U.S. Longline Grounds in the Western North Atlantic." Continental Shelf Research 13: 253-277. doi:10.1016/0278-4343(93)90109-B.

Polovina, J., I. Uchida, G. Balazs, E. A. Howell, D. Parker, and P. Dutton. 2006. "The Kuroshio Extension Bifurcation Region: A Pelagic Hotspot for Juvenile Loggerhead Sea Turtles." Deep Sea Research Part II: Topical Studies in Oceanography 53: 326-339. doi:10.1016/j. dsr2.2006.01.006.

Prasanna-Kumar, S., P. M. Muraleedharan, T. G. Prasad, M. Gauns, N. Ramaiah, S. N. DeSouza, S. Sardesai, and M. Madhupratap. 2002. "Why is the Bay of Bengal Less Productive during the Summer Monsoon Compared to the Arabian Sea?" Geophysical Research Letters 29 (24). doi:10.1029/2002GL016013.

Prasanna-Kumar, S., M. Nuncio, and J. Narvekar. 2004. “Are Eddies Nature's Trigger to Enhance Biological Productivity in the Bay of Bengal?" Geophysical Research Letters 31: L07309. doi:10.1029/2003GL019274.

Prasanna-Kumar, S., M. Nuncio, N. Ramaiah, S. Sardesai, J. Narvekar, V. Fernandes, and J. T. Paul. 2007. "Eddy-Mediated Biological Productivity in the Bay of Bengal during Fall and Spring Intermonsoons." Deep Sea Research Part I: Oceanographic Research Papers 54: 1619-1640. doi:10.1016/j.dsr.2007.06.002.

Ramos, A. G., J. Santiago, P. Sangra, and M. Canton. 1996. "An Application of Satellite Derived Sea Surface Temperature Data to the Skipjack (Katsuwonus pelamis Linnaeus, 1758) and Albacore Tuna (Thunnus alalunga Bonaterre, 1788) Fisheries in the North-East Atlantic." International Journal of Remote Sensing 17: 749-759. doi:10.1080/01431169608949042.

Rizal, R., P. Damm, M. A. Wahid, J. Sundermann, Y. Ilhamsyah, T. Iskandar, and Muhammad. 2012. "General Circulation in the Malacca Strait and Andaman Sea: A Numerical Model Study." American Journal of Environmental Sciences 8 (5): 479-488. doi:10.3844/ ajessp.2012.479.488.

Roy, S. D., and G. George. 2010. "Marine Resources of Islands: Status and Approaches for Sustainable Exploitation/Conservation with Special Emphasis to Andaman and Nicobar." Indian Journal of Animal Sciences 80 (4): 57-62.

Sabarros, P. S., F. Ménard, J. J. Lévénez, E. T. Kai, and J. F. Ternon. 2009. "Mesoscale Eddies Influence Distribution and Aggregation Patterns of Micronekton in the Mozambique Channel." Marine Ecology Progress Series 395: 101-107. doi:10.3354/meps08087.

Sánchez-Velasco, L., M. F. Lavín, S. P. A. Jiménez-Rosenberg, V. M. Godínez, E. Santamaría-delAngel, and D. U. Hernández-Becerril. 2013. "Three-Dimensional Distribution of Fish Larvae in a Cyclonic Eddy in the Gulf of California during the Summer." Deep Sea Research Part I: Oceanographic Research Papers 75: 39-51. doi:10.1016/j.dsr.2013.01.009.

Seki, M. P., R. Lumpkin, and P. Flament. 2002. "Hawaii Cyclonic Eddies and Blue Marlin Catches: The Case Study of the 1995 Hawaiian International Billfish Tournament." Journal of Oceanography 58: 739-745. doi:10.1023/A:1022854609312.

Seki, M. P., J. J. Polovina, R. R. Brainard, R. R. Bidigare, C. L. Leonard, and D. G. Foley. 2001. "Observations of Biological Enhancement at Cyclonic Eddies Tracked with GOES Thermal Imagery in Hawaiian Waters." Geophysical Research Letters 28: 1583-1586. doi:10.1029/ 2000 GL012439.

Solanki, H. U., R. M. Dwivedi, S. R. Nayak, S. K. Naik, M. E. John, and V. S. Somvanshi. 2005. "Application of Remotely Sensed Closely Coupled Biological and Physical Processes for 
Marine Fishery Resources Exploration." International Journal of Remote Sensing 26: 2029-2034. doi:10.1080/01431160310001595028.

Stapleton, N. R., W. T. Aicken, P. R. Dovey, and J. C. Scott. 2002. "The Use of Radar Altimeter Data in Combination with Other Satellite Sensors for Routine Monitoring of the Ocean: Case Study of the Northern Arabian Sea and Gulf of Oman." Canadian Journal of Remote Sensing 28 (4): 567-572. doi: $10.5589 / \mathrm{m} 02-053$.

Stretta, J. M. 1991. "Forecasting Models for Tuna Fishery with Aerospatial Remote Sensing." International Journal of Remote Sensing 12: 771-779. doi:10.1080/01431169108929693.

Varkey, M. J., V. S. N. Murty, and A. Sur Yanarayana 1996. "Physical Oceanography of the Bay of Bengal." In Oceanography and Marine Biology: An Annual Review, edited by A. D. Ansell, R. N. Gibson, and M. Barnes, No. 34, 1-70. London: University College London Press.

Welch, B. L. 1951. "On the Comparison of Several Mean Values: An Alternative Approach." Biometrika 38: 330-336. doi:10.1093/biomet/38.3-4.330.

Yoder, J. A., L. P. Atkinson, T. N. Lee, H. H. Kim, and C. R. McClain. 1981. "Role of Gulf Stream Frontal Eddies in Forming Phytoplankton Patches on the Outer Southeastern Shelf." Limnology and Oceanography 26: 1103-1110. doi:10.4319/lo.1981.26.6.1103.

Zainuddin, M., H. Kiyofuji, K. Saitoh, and S.-I. Saitoh. 2006. "Using Multi-Sensor Satellite Remote Sensing and Catch Data to Detect Ocean Hotspots for Albacore (Thunnus alalunga) in the Northwestern. North Pacific." Deep Sea Research Part II: Topical Studies in Oceanography 53: 419-431. doi:10.1016/j.dsr2.2006.01.007. 